\title{
Critical Review of Solidification of Sandy Soil by Microbially Induced Carbonate Precipitation (MICP)
}

\author{
Liuxia Chen ${ }^{1,2}$, Yuqi Song ${ }^{3, *} \mathbb{C}$, Jicheng Huang ${ }^{4}$, Chenhuan Lai ${ }^{1,2}$, Hui Jiao ${ }^{1,2}$, Hao Fang ${ }^{5}$, Junjun Zhu ${ }^{1,2}$ \\ and Xiangyang Song $1,2, *$ \\ 1 College of Chemical Engineering, Nanjing Forestry University, Nanjing 210037, China; clx@njfu.edu.cn (L.C.); \\ LCH2014@njfu.edu.cn (C.L.); jiaohui2021@outlook.com (H.J.); zhujj@njfu.edu.cn (J.Z.) \\ 2 Key Laboratory of Forestry Genetics \& Biotechnology, Ministry of Education, Nanjing Forestry University, \\ Nanjing 210037, China \\ 3 Department of Civil Engineering, Monash University, Melbourne 3800, Australia \\ 4 Department of Engineering Mechanics, School of Civil Engineering, Southeast University, \\ Nanjing 210096, China; 220190985@seu.edu.cn \\ 5 College of Life Sciences, Northwest A\&F University, Xianyang 712100, China; fanghao@nwsuaf.edu.cn \\ * Correspondence: yuqi.song@monash.edu (Y.S.); xysongnanlin@njfu.edu.cn (X.S.)
}

Citation: Chen, L.; Song, Y.; Huang, J.; Lai, C.; Jiao, H.; Fang, H.; Zhu, J.; Song, X. Critical Review of Solidification of Sandy Soil by Microbially Induced Carbonate Precipitation (MICP). Crystals 2021, 11, 1439. https://doi.org/10.3390/ cryst11121439

Academic Editors: Hamed

Khodadadi Tirkolaei,

Satoru Kawasaki, Liang Cheng,

Leon van Paassen and José L. Arias

Received: 19 October 2021

Accepted: 17 November 2021

Published: 23 November 2021

Publisher's Note: MDPI stays neutral with regard to jurisdictional claims in published maps and institutional affiliations.

Copyright: (c) 2021 by the authors. Licensee MDPI, Basel, Switzerland. This article is an open access article distributed under the terms and conditions of the Creative Commons Attribution (CC BY) license (https:// creativecommons.org/licenses/by/ $4.0 /)$.

\begin{abstract}
Microbially induced carbonate precipitation (MICP) is a promising technology for solidifying sandy soil, ground improvement, repairing concrete cracks, and remediation of polluted land. By solidifying sand into soil capable of growing shrubs, MICP can facilitate peak and neutralization of $\mathrm{CO}_{2}$ emissions because each square meter of shrub can absorb 253.1 grams of $\mathrm{CO}_{2}$ per year. In this paper, based on the critical review of the microbial sources of solidified sandy soil, models used to predict the process of sand solidification and factors controlling the MICP process, current problems in microbial sand solidification are analyzed and future research directions, ideas and suggestions for the further study and application of MICP are provided. The following topics are considered worthy of study: (1) MICP methods for evenly distributing $\mathrm{CaCO}_{3}$ deposit; (2) minimizing $\mathrm{NH}_{4}{ }^{+}$production during MICP; (3) mixed fermentation and interaction of internal and exogenous urea-producing bacteria; (4) MICP technology for field application under harsh conditions; (5) a hybrid solidification method by combining MICP with traditional sand barrier and chemical sand consolidation; and (6) numerical model to simulate the erosion resistance of sand treated by MICP.
\end{abstract}

Keywords: micro-organism; urease; curing; sandy soil; desertification

\section{Introduction}

Microbially induced carbonate precipitation (MICP) is a promising technology applied to many civil and environmental engineering scenarios, especially combating desertification [1]. Desertification refers to the process of land degradation in arid, early semi-dry, and arid and subhumid areas under the action of various factors, including climate and human activities. The severe problem of global desertification is caused by natural and human factors, climate change, wind and rain erosion of the soil, the pursuit of economic benefits, destruction of vegetation, and unreasonable use of water resources, all of which aggravate the formation of desertification. Because the emergence of desertification has caused a significant impact on the environment and economical construction, it is highly urgent to control it [2]. Kimura et al. [3] classified and counted the global dry areas in 2017 according to the satellite-based aridity index (SbAI). Figure 1 [3] shows areas of global arid areas in 2017 and their proportion in the total land area. It can be seen from Figure 1 [3] that the total area of global arid areas accounts for $41 \%$ of the total land area. Figure 2 [4] shows the global desertification risk level distribution map from 2000 to 2014, estimated based on the global Desertification Vulnerability Index and the ratio of areas with different risk levels. The colors in Figure 1 represent different levels of global desertification risk. 


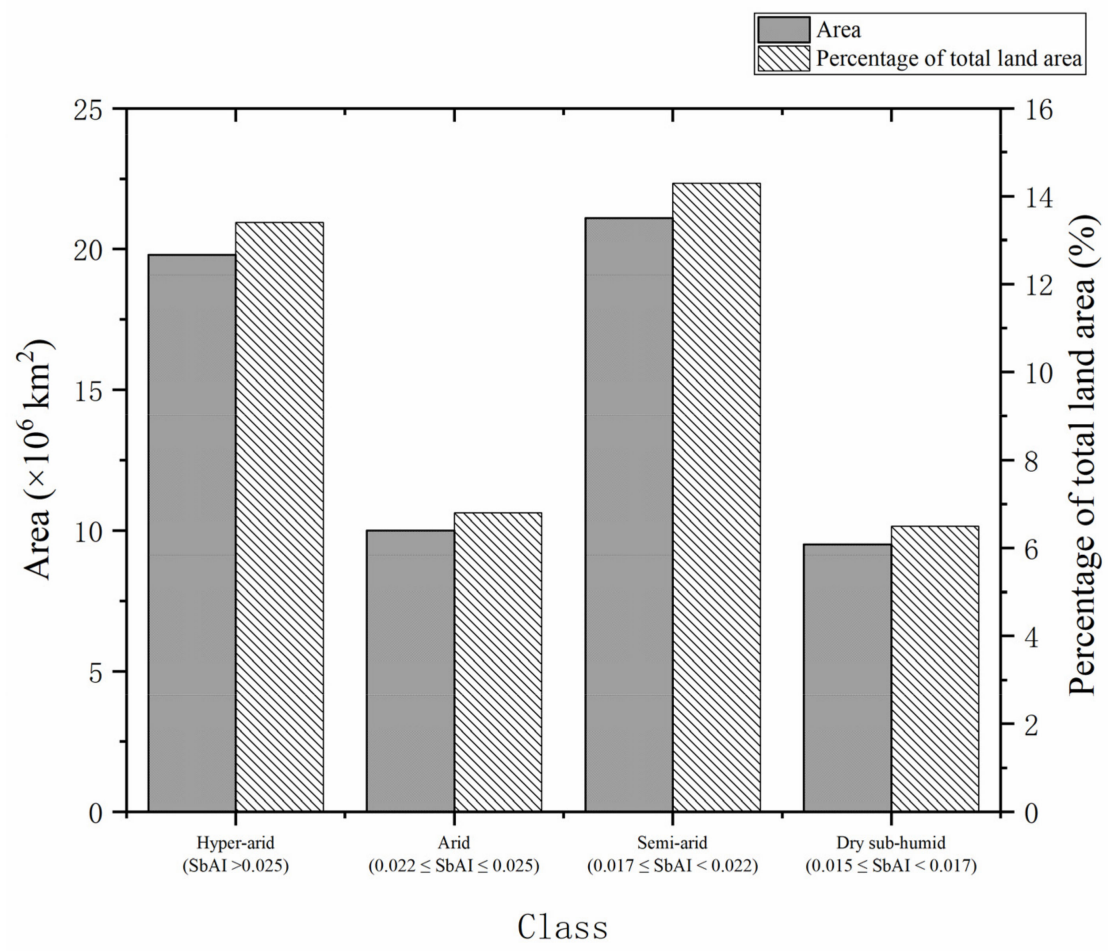

Figure 1. Schematic diagram of arid areas worldwide and their percentage of total land area in 2017 based on the Satellite Drought Index (SbAI) [3].

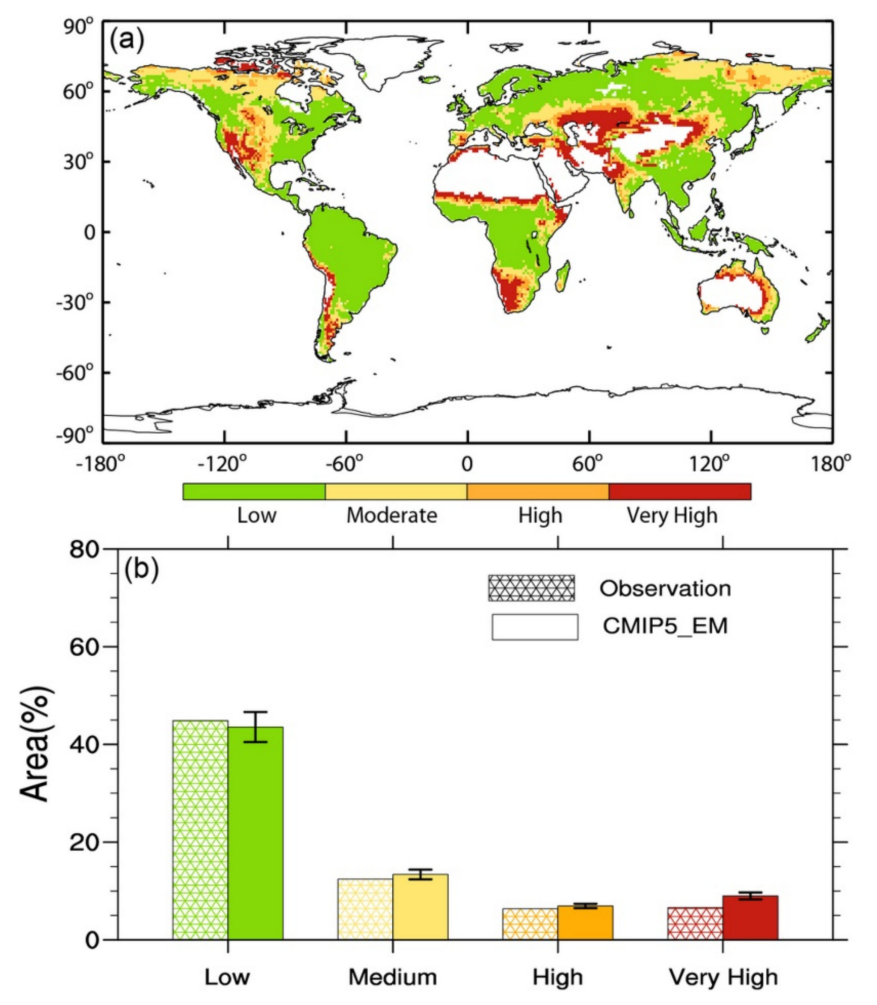

Figure 2. (a) The global desertification risk level distribution from 2000 to 2014, estimated based on the Global Desertification Vulnerability Index; (b) The proportion of areas with different desertification risk levels in the global land area [4].

Sand consolidation uses various ways to reduce the sand porosity and fix the sand particles [5]. As one of the common ways of consolidation, grouting consolidation is defined as 
applying pressurized grouting slurry to infiltrate within the void of sandy soil, followed by the compaction and solidification of sand along with the slurry [6]. The grouting method usually includes the chemical grouting method and the biological grouting method $[7,8]$. In the early stage, methods of sand consolidation in desertification were limited to chemical grouting with cement, lime, and other chemical materials. However, various sand consolidation methods emerged following extensive research, including sand fixation with the sand barrier, chemicals, and microbial grouting [7-9]. The grouting method can only be used for coarse sand with a particle size greater than $4.75 \mathrm{~mm}$, and microbial sand consolidation can be used for fine or medium sand with less than $0.6 \mathrm{~mm}$ [10]. Chemical grouting methods cost less, but chemical grouting materials (e.g., cement, lime, or adhesive) are harmful to the environment. The microbial grouting method has a relatively high cost but is friendly to the environment and can effectively improve the properties of sand $[7,8]$. Figure 3 [6] shows a schematic diagram of the grouting method. Microbial sand fixation refers to adding cementation solution to stimulate bacteria and then forming calcium carbonate crystals in the sand to consolidate the sand. Cementation solution generally refers to a mixture of calcium salts, nutrients and urea. Figure 4 [11] shows a diagram of the experimental setup for MICP. Microbial sand fixation not only has the advantages of environmental protection, low pollution, effective maintenance of soil moisture in sandy deserts, improvement of soil fertility, and improvement of soil thermal conductivity, but can also turn the sandy desert into soil and increase the area of state-owned arable land, which is of practical significance for the curbing of desertification. Countries around the world put forward the strategic goal of carbon peak, and carbon neutrality due to global climate change leads to many extreme climate events. "Peak carbon" refers to when carbon dioxide emissions reach a peak and then stop rising and gradually fall back. Carbon neutrality means achieving zero carbon dioxide emissions by offsetting total greenhouse gas emissions through afforestation, energy conservation, and emission reduction. The United States and the European Union have announced carbon neutrality by 2050 and China by 2060. Microbial sand fixation can also facilitate carbon peaking and carbon neutralization because microbial sand solidification technology can enable the sand to grow shrubs. Li et al. [12] found that each square meter of shrub can absorb 253.1 grams of carbon dioxide per year. All in all, microbial sand fixation has gradually become an important research topic [13,14].

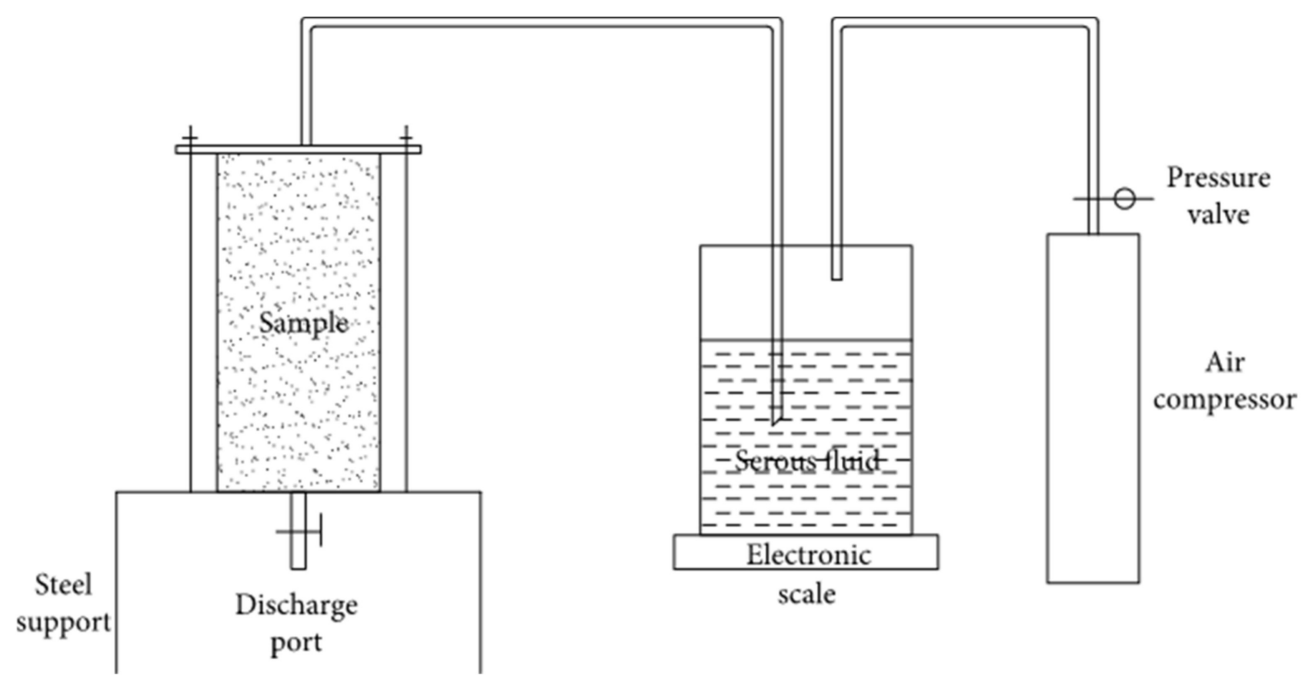

Figure 3. Schematic diagram of grouting consolidation device [6]. 

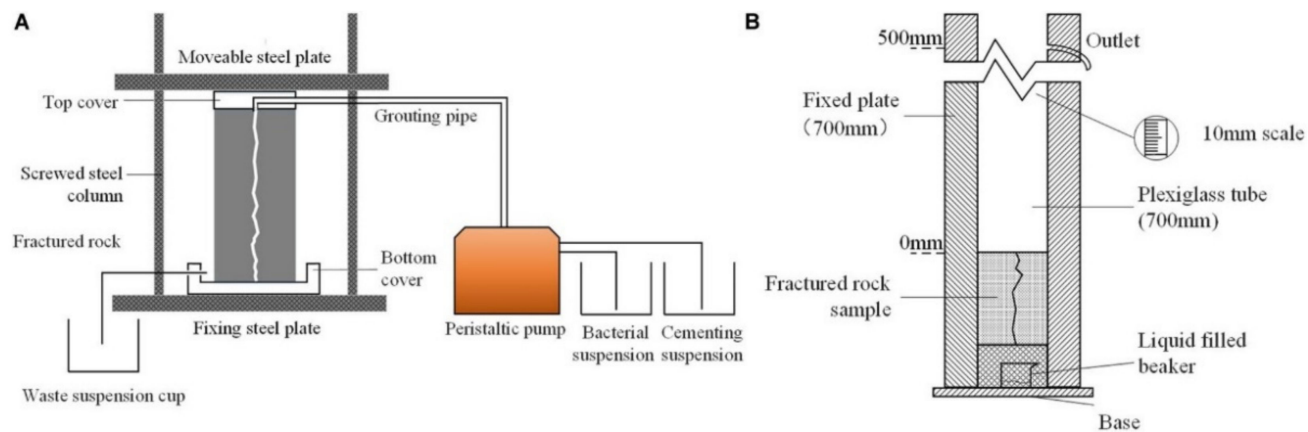

Figure 4. Schematic diagram of MICP experimental device. (A) Grouting device; (B) Seepage device [11].

The source of the urease-producing microbe of MICP can be indigenous or exogenous [15-17]. If the urease activity of the local (indigenous) urease-producing bacteria is high, the local bacteria can be directly used for the sand fixation. However, if the activity of local urease-producing bacteria is low, the cementation solution with nutrients should be added to stimulate the local bacteria to produce enough urease. In addition, exogenous urease-producing bacteria can be added to increase the effect of microbial sand consolidation. After treatment with MICP technology, the porosity and water conductivity of soil are reduced due to the combination of $\mathrm{CaCO}_{3}$ precipitation and the medium, and the soil after solidification is not easily liquified by the action of earthquakes [18-20]. Due to the tiny pores in the clays, it is difficult for the bacteria to enter the clays, and therefore there are few studies on the microbial solidification of clays. Liu et al. [21] studied the effect of MICP on the repair of dry cracks in clays. Sun et al. [22] treated a sand-clay mixture with MICP and found that different amounts of clays need to be added to solidify sand with different particle sizes.

Microbial sand fixation technology is not limited to small-scale laboratory studies but is also applied to large-scale outdoor studies. Figure 5 [23] and Figure 6 [24] are photos of extensive outdoor experiments. Figure 7 [25] is a schematic diagram of the test system. Meng et al. [26] conducted outdoor experiments in Ulan Buh Desert, and the results confirmed that the use of Sporosarcina pasteurii to consolidate desert soil could improve the wind erosion resistance of soil. Outdoor microbial sand fixation experiments need to overcome many difficulties and the cost is relatively high. According to the results of small sand fixation experiments in the laboratory, part of the results of large outdoor experiments can be predicted by using the model [27].

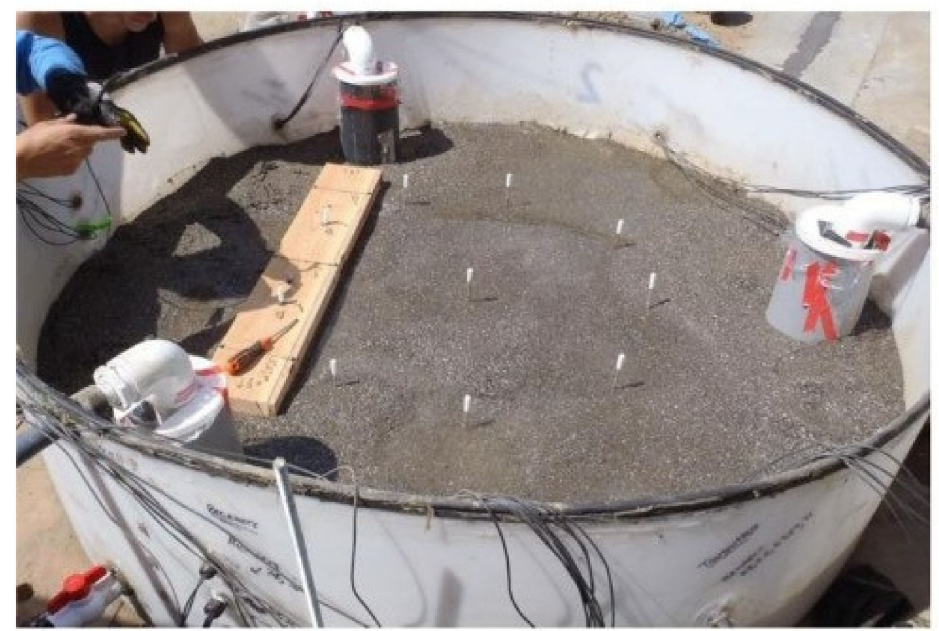

Figure 5. Photos of microbial sand fixation in the field [23]. 

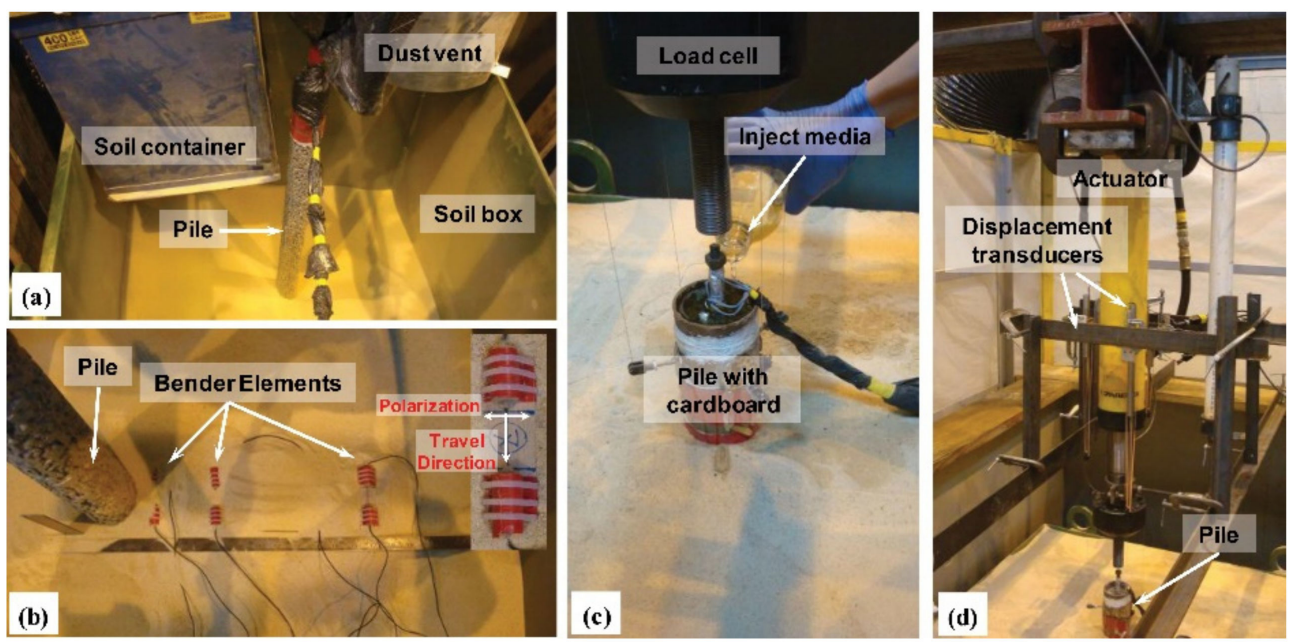

Figure 6. Detailed device drawing for large MICP grouting (a) soil raining; (b) bender element installation; (c) media injected from the top of the pile; (d) pull-out loading setup [24].

(a)

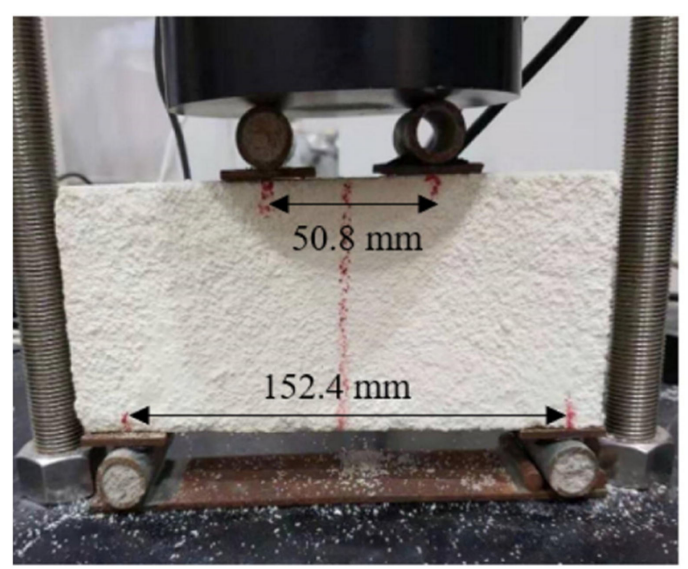

(b)

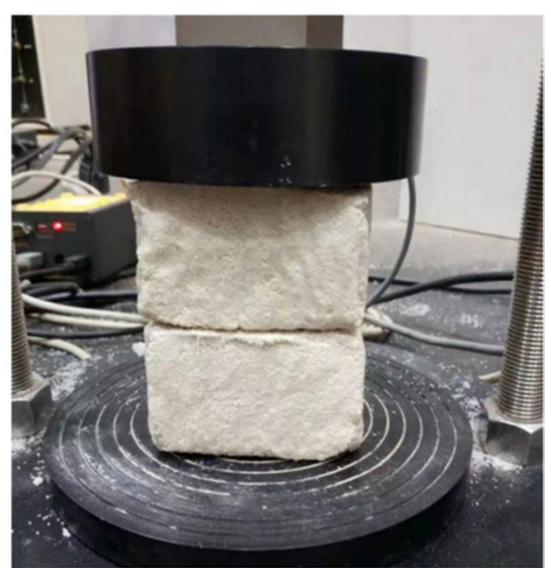

Figure 7. Schematic diagram of MICP test system. (a) Four-point bending test system; (b) Compressive strength testing system [25].

Microbial sand consolidation is affected by many factors, such as the concentration of the cementation solution, the concentration of culture liquid, temperature, calcium source and $\mathrm{pH}$ value. After optimizing various factors, the solidification effect of the sand body after microbial solidification can be effectively improved [28]. Micro-organisms can induce $\mathrm{CaCO}_{3}$ to cement the curing medium, and the degree of curing needs to be measured or characterized by microscopic photographs taken by precision instruments. Scanning electron microscopy (SEM), light microscopy and other instruments are usually used to observe the generated calcium carbonate crystals, which can more intuitively reflect the effect of microbial sand consolidation. There are other methods to characterize the solidification effect of microbial cementation based on microscopic photographs, the determination of $\mathrm{CaCO}_{3}$ content, permeability, shear wave velocity, Fourier transforms infrared spectrum analysis, and scanning electron microscopy [29-31].

MICP technology has dramatically developed in the past ten years in laboratory-scale solidified sand. However, there are still many challenges to overcome in applying MICP to field-scale practical engineering. Due to the long study cycle of MICP sand treatment and the high cost of large-scale field operations, few studies have been conducted on large-scale outdoor solidified sand [1]. In addition, the application of MICP to the harsh environment, including high temperatures, freeze-thaw cycles, wet-dry conditions, and acid rain, needs further study [32]. Ammonium ions produced during MICP can be hazardous to the 
environment if left untreated [33]. The removal method of the ammonium ion should also be further studied in the future.

In this paper, progress in the research on microbial mineralized sandy soil is summarized, including ways of solidifying sandy soil, microbial sources of solidified sand, models used to predict the curing process of MICP in the field, factors that influence microbial solidification of sandy soil, the analysis of current problems and discussion on the prospects for the application of microbial sand consolidation technology in the future.

\section{Methods of Solidifying Sand}

As desertification increases, the local ecological environment and economy are greatly affected, and the continuous expansion of areas of desertification correspondingly reduces the arable area [34]. If desertification can be effectively contained, it will be beneficial to the ecological environment and economic development. In order to curb the spread of desertification, the government and relevant departments have proposed many solutions, such as reducing the destruction of forests and protecting vegetation [35]. At present, the main methods of solidifying sand include microbial sand consolidation and other sand fixation methods. Each method has advantages and disadvantages. In practical applications, the most appropriate cure should be selected according to specific conditions, such as the nature of the solidified sample and the external environment [36].

\subsection{Microbial Sand Consolidation}

In the past, researchers focused on the geological processes of soil. With the rapid development of microbiology, researchers began to discuss the impact of microbial activity on the mechanical properties of soil. Microbial sand consolidation technology is a product of microbial application in the field of geotechnical engineering [37]. Large-scale experiments have verified that microbial sand consolidation can improve the foundation and increase the strength of granular soil through microbial grouting [38]. Venuleo et al. [39] solidified silica sand with Sporosarcina pasteurii; the grain density of silica sand is $2.65 \mathrm{~g} / \mathrm{cm}^{3}$, the concentrations of calcium chloride and urea were both $0.25 \mathrm{M}$, and the batch grouting times were 16. The results showed that the calcium carbonate content of the solidified sand was $0.13 \mathrm{~g} / \mathrm{cm}^{3}$ and the thermal conductivity of the soil was increased by $250 \%$ compared with that of untreated soil. The thermal conductivity of sand refers to the heat transferred through a unit horizontal cross-sectional area per unit time. The increase in thermal conductivity was due to the formation of calcium carbonate, which increased the contact area between sand particles and thus promoted heat transfer.

MICP can utilize four types of bacteria: urease-producing bacteria, denitrifying bacteria, sulfate-reducing bacteria, and ferric-reducing bacteria. It is most commonly used in the laboratory to strengthen sandy soil by urea hydrolysis of urease-producing bacteria [40]. Microbial sand consolidation by urease-producing bacteria is achieved by adding the microbial solution to sand, then adding the cementation solution consisting of urea and calcium chloride solution after standing for a while. The microorganisms used in the cultured liquid are preferably slightly aerobic or facultative anaerobic [41]. There are many species of urea-producing bacteria, including B. megaterium, Pararhodobacter sp., and Sporosarcina pasteurii. Table 1 lists some urea-producing bacteria which have been found and the sources of these bacteria. 
Table 1. MICP research using various urea-producing bacteria.

\begin{tabular}{|c|c|c|}
\hline The Name of the Bacteria & The Sources of the Bacteria & References, Year \\
\hline Sporosarcina pasteurii MTCC 1761 & $\begin{array}{c}\text { The Institute of Microbial Technology, } \\
\text { Chandigarh, } \\
\text { India }\end{array}$ & [42], 2009 \\
\hline B. megaterium ATCC 14581 & American Type Culture Collection & [43], 2013 \\
\hline Pararhodobacter sp. & $\begin{array}{l}\text { The soil near beach rock in Sumuide, Nago } \\
\text { Okinawa, Japan }\end{array}$ & [44], 2018 \\
\hline $\begin{array}{l}\text { Staphylococcus saprophyticus subsp. } \\
\text { saprophyticus }\end{array}$ & & \\
\hline $\begin{array}{c}\text { Sporosarcina globispora } \\
\text { Bacillus lentus strain NCIMB8773 } \\
\text { Sporosarcina sp. } \\
\text { Bacillus pasteurii NCIM } 2477\end{array}$ & Calcareous sand and limestone cave soils & [45], 2016 \\
\hline $\begin{array}{c}\text { Brevibacterium ammoniagenes } \\
\text { ATCC 6871 } \\
\text { Bacillus lentus 2466-NCIB } 8773\end{array}$ & $\begin{array}{l}\text { The National Collection of Industrial } \\
\text { Microorganisms (NCIM) }\end{array}$ & [46], 2009 \\
\hline $\begin{array}{l}\text { B. licheniformis ATCC } 14580 \\
\text { S. pasteurii ATCC } 11859\end{array}$ & American Type Culture Collection & [47], 2019 \\
\hline S. pasteurii BNCC 337394 & BeNa Culture Collection & [48], 2020 \\
\hline Bacillus sp. DSM 23526 & $\begin{array}{c}\text { Deutsche Sammlung von Mikroorganismen } \\
\text { und Zellkulturen (DSMZ) }\end{array}$ & [49], 2014 \\
\hline E. undae YR10 & $\begin{array}{l}\text { Isolated from Yangtze River near } \\
\text { Chongming County, Shanghai, China }\end{array}$ & [50], 2014 \\
\hline Bacillus velezensis & Isolated from native Indian soil & [51], 2020 \\
\hline $\begin{array}{l}\text { Pseudomonas nitroreducens } \\
\text { szh_asesj15 }\end{array}$ & Isolated from landfill groundwater & {$[52], 2021$} \\
\hline $\begin{array}{l}\text { Bacillus sp. xjlu_herc15 } \\
\text { Bacillus licheniformis adseedstjo15 }\end{array}$ & $\begin{array}{l}\text { Isolated from leachate } \\
\text { Isolated from leachate }\end{array}$ & \\
\hline $\begin{array}{l}\text { Lysinibacillus xylanilyticus } \\
\text { Psychrobacillus sp }\end{array}$ & Isolated from Hokkaido, Japan & $\begin{array}{l}{[53], 2019} \\
{[54], 2019}\end{array}$ \\
\hline
\end{tabular}

The bacterium commonly used in sand consolidation is Sporosarcina pasteurii [55]. The MICP principle based on urease-producing bacteria is that urease-producing bacteria produce urease in a suitable growth environment, and urease promotes the hydrolysis of urea to produce $\mathrm{CO}_{3}{ }^{2-}$, as it reacts with $\mathrm{Ca}^{2+}$ to produce $\mathrm{CaCO}_{3}$ precipitation. The specific reaction equations are shown in Equations (1) and (2). It can be seen from Equation (1) that the microbial sand consolidation with urease bacteria will produce the by-product of $\mathrm{NH}_{4}{ }^{+}$, and the high concentration of $\mathrm{NH}_{4}{ }^{+}$will harm the environment if not treated [56]. There are many studies on ammonium removal. Keykha et al. [57] used Sporoscarcina pasteurii to generate carbonate ions in the process of culture. Then, natural zeolite was used to remove ammonium ions generated in the process of culture order to prevent the damage of ammonium ions to the soil environment, including vegetation and groundwater resources. The experiment results showed that negatively charged zeolite could absorb $\mathrm{NH}_{4}{ }^{+}$to standard levels (i.e., less than $0.5 \mathrm{mg} / \mathrm{L}$ ). Gowthaman et al. [58] used struvite to significantly reduce ammonium produced as a by-product during MICP by a two-step method. In the first stage, the conditions of rinsing were studied to optimize ammonia removal from soil. In the second stage, the influence of the $\mathrm{pH}$ condition, ammonia mole ratio, and calcium ion on struvite precipitation were studied. Research showed that struvite precipitation could remove about $90 \%$ of ammonia. Gowthaman et al. [59] controlled the $\mathrm{pH}$ of the reaction process by changing the content of urea so that the curing process was in a different $\mathrm{pH}$ range, and the morphology of the generated calcium phosphate precipitation changed with the change of $\mathrm{pH}$. The experiment results showed that calcium phosphate biocementation at $\mathrm{pH} 3.4-7.5$ can reduce the release of ammonium ions by about $50 \%$ and toxic ammonia by approximately $90 \%$ in the environment in comparison with conventional biocementation [59]. Therefore, future studies can be focused on minimizing the by-product of $\mathrm{NH}_{4}{ }^{+}$to make the MICP technology more environmental-friendly. Figure 8 [60] shows the schematic diagram of MICP based on urease-producing bacteria. Figure 9 [61] shows the processing steps, and detection process of MICP applied to solidified sand.

$$
\mathrm{CO}\left(\mathrm{NH}_{2}\right)_{2}+3 \mathrm{H}_{2} \mathrm{O}=\mathrm{HCO}_{3}^{-}+2 \mathrm{NH}_{4}^{+}+\mathrm{OH}^{-}
$$




$$
\mathrm{Ca}^{2+}+\mathrm{HCO}_{3}{ }^{-}+\mathrm{OH}^{-}=\mathrm{CaCO}_{3} \downarrow+\mathrm{H}_{2} \mathrm{O}
$$

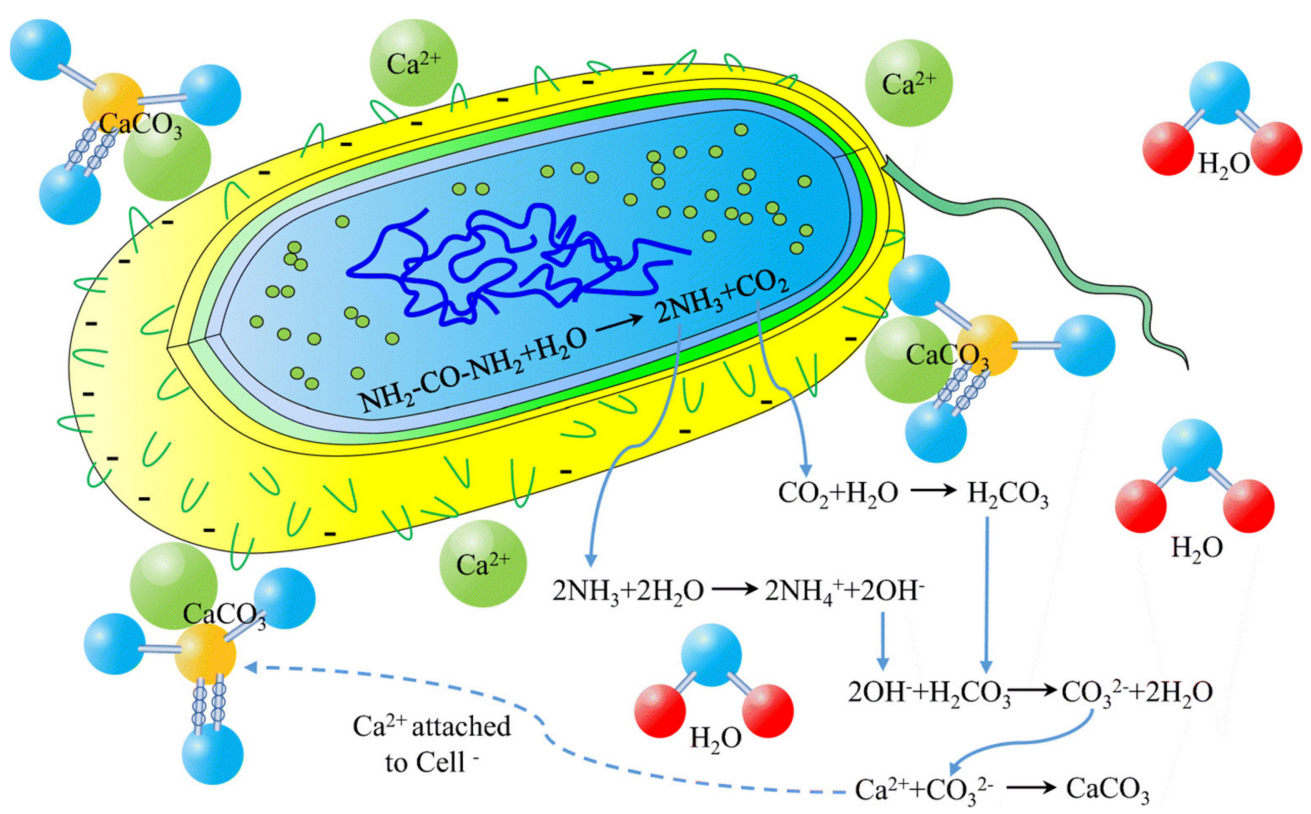

Figure 8. Schematic diagram of MICP based on urease-producing bacteria [60].

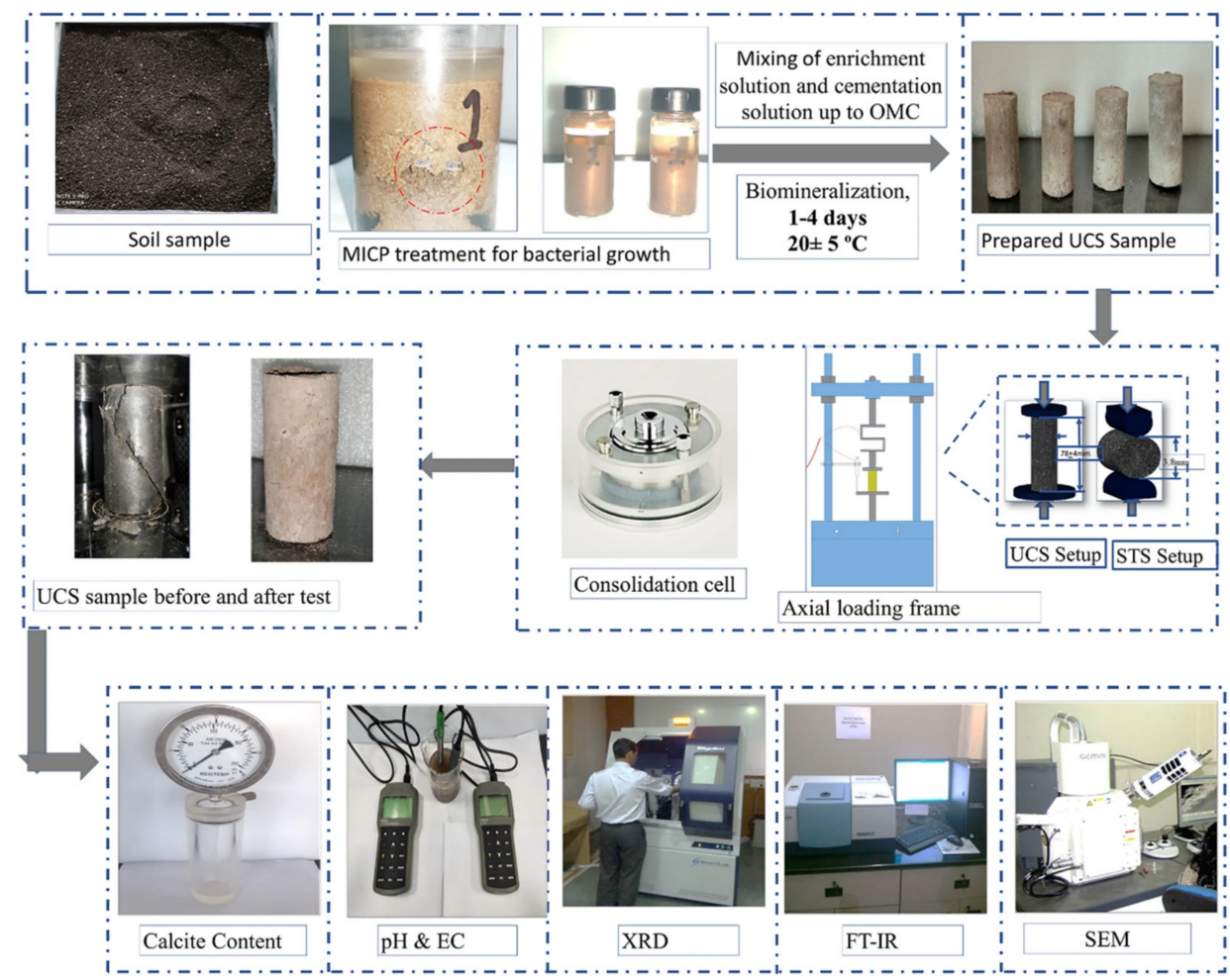

Figure 9. Detailed treatment procedures and testing procedures for microbial solidified sand [61].

The stability of the mechanical properties of bio-consolidated sand can also be affected by freeze-thaw cycles, wet-dry conditions, and acid rain. MICP-treated slope soil has a certain tolerance to freeze-thaw erosion, and the degree of cementation largely determines the overall stability [62]. Sharma et al. [63] studied the effects of freeze-thaw cycles on shear strength and shear modulus of Narmada river sand treated with MICP under different conditions. The experiment results showed that after 5 and 10 freeze-thaw 
cycles, the strength of all biologically treated samples decreased by less than $5 \%$ and $10 \%$. Sun et al. [32] found that slopes treated with MICP-polyacrylamide have good freeze-thaw durability and soil loss was still small after 12 freeze-thaw cycles. Gowthaman et al. [62] found that when subjected to 25 cycles of frost, samples bonded to an average of $11-13 \%$ $\left(\mathrm{CaCO}_{3}\right.$ mass) were high eroded ( $50 \%$ mass loss), while samples bonded to $20-23 \%$ only slightly eroded ( $2 \%$ mass loss). Sharma et al. [64] found that after 20 wet-dry cycles, the mass loss rate of samples with calcite precipitation amount (10.2-12\%) was less than $3 \%$, and the total mass of the minimum precipitation samples (3.25-3.89\%) remained above $70 \%$. Gowthaman et al. [65] studied the influence of acid rain conditions on the durability of MICP-treated slope soil and found that when $\mathrm{CaCO}_{3}$ content was $12.5 \%$, the soil loss rate was $19.9 \%$, while when cemented $\mathrm{CaCO}_{3}$ content was $22.5 \%$, soil loss rate decreased to $5.4 \%$.

The biomass of Sporosarcina pasteurii is generally proportional to the amount of urease produced. After culturing, the bacteria surface with a strong negative charge is conducive to the formation of $\mathrm{CaCO}_{3}$ through the combination of $\mathrm{Ca}^{2+}$, which is highly adaptable to the environment [48]. In addition to the urea-producing bacteria, the presence of non-urease bacteria also accelerates the MICP reaction process. Gat et al. [47] studied the influence of the interaction between Sporosarcina pasteurii and non-urease bacterium Bacillus subtilis on the MICP effect, and showed that the rate of precipitation $\mathrm{CaCO}_{3}$ from both bacteria was faster than that from Sporosarcina pasteurii alone.

In the case of low urease activity of the local bacteria, the introduction of exogenous urease bacteria to solidify the sand achieves good results. Tobler et al. [66] found that in the case of low urease activity of local bacteria, the introduction of Sporosarcina pasteurii promotes the rapid formation of precipitation in oxygenated and anoxic groundwater. Nevertheless, the cost of a urea-producing culture medium is high. In order to reduce the cost of culture medium for urea-producing bacteria, researchers have found economical alternative culture mediums [67]. The urease activity of the urease bacteria cultured by the alternative culture medium is almost the same as that of the urease bacteria cultured by the standard culture medium. Table 2 lists some economic mediums which have been found to replace standard media for urea-producing microorganisms. Figure 10 [68] shows the metabolic process of urease-producing bacteria using dairy wastewater.

Table 2. Economical alternatives to medium nutrient sources.

\begin{tabular}{|c|c|c|c|}
\hline The Name of the Bacteria & Economical Alternatives & $\begin{array}{l}\text { Substitution of Nutrients in } \\
\text { the Medium }\end{array}$ & References, Year \\
\hline Sporosarcina pasteurii & Corn-steep liquor & Protein & [69], 2011 \\
\hline Sporosarcina pasteurii NCIM 2477 & Lactose mother liquor & Protein & [70], 2009 \\
\hline Sporosarcina pasteurii NB28 & Food-grade yeast & Nitrogen source & [71], 2019 \\
\hline Sporosarcina pasteurii & $\begin{array}{c}\text { By-products coming from the } \\
\text { dairy and brewery industries } \\
\text { Fertilizer urea }\end{array}$ & $\begin{array}{c}\text { Protein } \\
\text { Urea }\end{array}$ & [72], 2015 \\
\hline $\begin{array}{l}\text { Sporosarcina pasteurii isolated from } \\
\text { agricultural soils of Sotaquirá and Nobsa }\end{array}$ & Whey & Protein & [73], 2021 \\
\hline S. pasteurii DSMZ 33 & Corn-steep liquor & Carbon source & [74], 2018 \\
\hline Bacillus pasteurii КСТС 3558 & $\begin{array}{l}\text { Effluent from chicken manure } \\
\text { bio-gas plant }\end{array}$ & Protein & [75], 2016 \\
\hline Psychrobacillus sp. & Beer Yeast & Nitrogen source & [76], 2019 \\
\hline
\end{tabular}




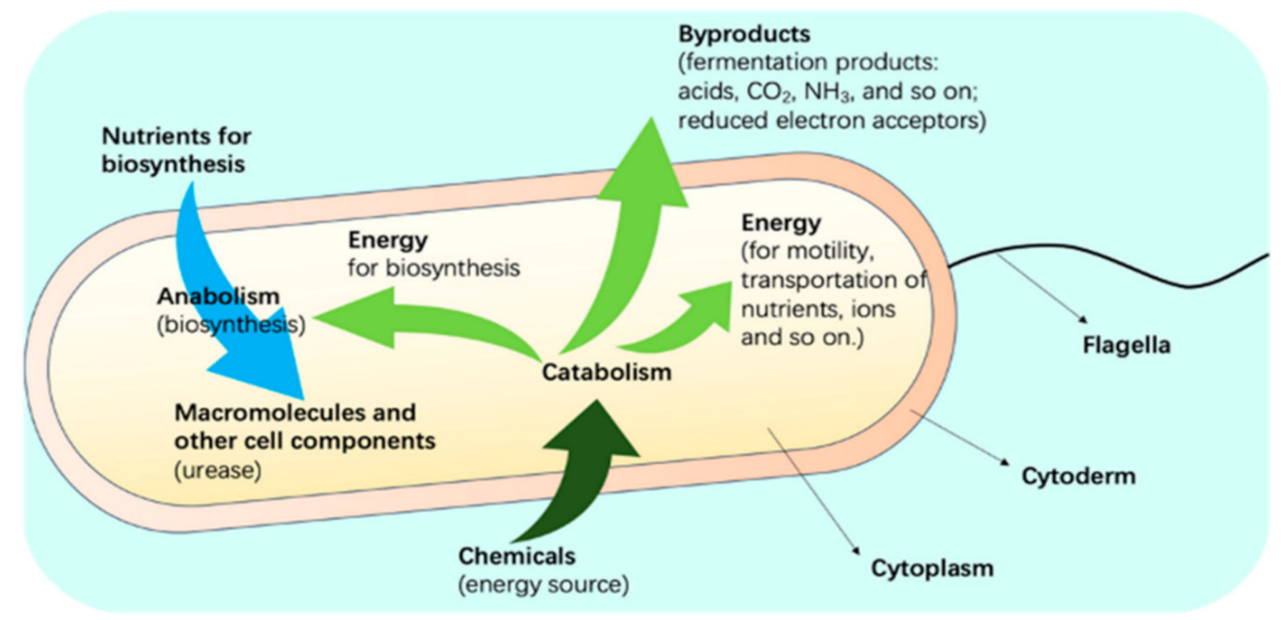

Figure 10. The metabolic process of urease-producing bacteria using dairy wastewater [68].

\subsection{Other Sand Fixation Methods}

At present, in addition to MICP sand fixation, the sand barrier, chemical sand consolidation, and solidification of sand by enzyme-induced carbonate precipitation (EICP) technology can also be used to fix sand.

Sand fixation with the sand barrier is a sand barrier made of clay, fences, and plants. By changing the properties of the underlying surface and increasing the roughness of the surface, sand barriers can prevent wind and sand consolidation and reduce the impact of wind and rain on sand erosion [77]. Chemical sand consolidation involves spraying chemical adhesive materials on the surface of sandy soil to make the surface sand particles bond to or infiltrate the chemical bonding material into sandy soil, so that the internal sand particles bond together to form a protective layer that plays the role of wind and sand consolidation, and improves the permeability of water in sandy soil. MICP technology and EICP technology both belong to biological cementation technology. MICP induces calcium carbonate precipitation by bacteria, and EICP generates calcium carbonate precipitation through hydrolysis of urea catalyzed by plant-derived urease enzymes. The performance of EICP may be affected by the source and activity of the enzyme, the calcium concentration, and the EICP treatment method [78].

Sand fixation with the sand barrier, chemical sand fixation, solidification of sand by EICP technology, and microbial sand fixation have distinct advantages and disadvantages. The most suitable sand fixation technology should be selected according to local environmental conditions. Table 3 lists the advantages and disadvantages of sand barriers, solidification of sand by EICP technology, chemical, and MICP. The cost of sand barriers and chemical sand fixation is relatively low, and the cost of MICP and EICP technologies is high. Sand fixation with sand barrier has advantages, including good sand consolidation, environmental friendliness, and convenient operation. However, sand barriers of grass grids need to be set carefully, considering factors such as wind direction and the sand's direction with wind movement; otherwise, they may not affect sand consolidation [79]. Most chemical sand fixing materials have significant economic benefits, but the chemicals used are often toxic to the environment, which is not environmentally friendly. Sand fixation with the sand barrier cannot improve the characteristics of desert sand. Chemical sand fixation, the solidification of sand by EICP and MICP technologies, can improve the characteristics of desert sand. Compared with MICP, EICP can be applied to finer sand due to the smaller particle size of the enzyme than microbe [80], and there is no need to cultivate bacteria in the EICP. Therefore, EICP is easier to operate. However, the commercial pure urease enzyme is expensive, and extraction techniques may involve additional processes and chemicals [78]. MICP cannot be used to treat soil with pores smaller than $0.5 \mu \mathrm{m}$ due to the diameter of the microbe being larger than $0.5 \mu \mathrm{m}$ and the complexity of 
bacterial cultures used in MICP [80]. Because the urease of MICP is produced by bacteria, an appropriate environment needs to be maintained to generate enough urease with high activity [80].

Table 3. Comparison of advantages and disadvantages of various sand consolidation methods.

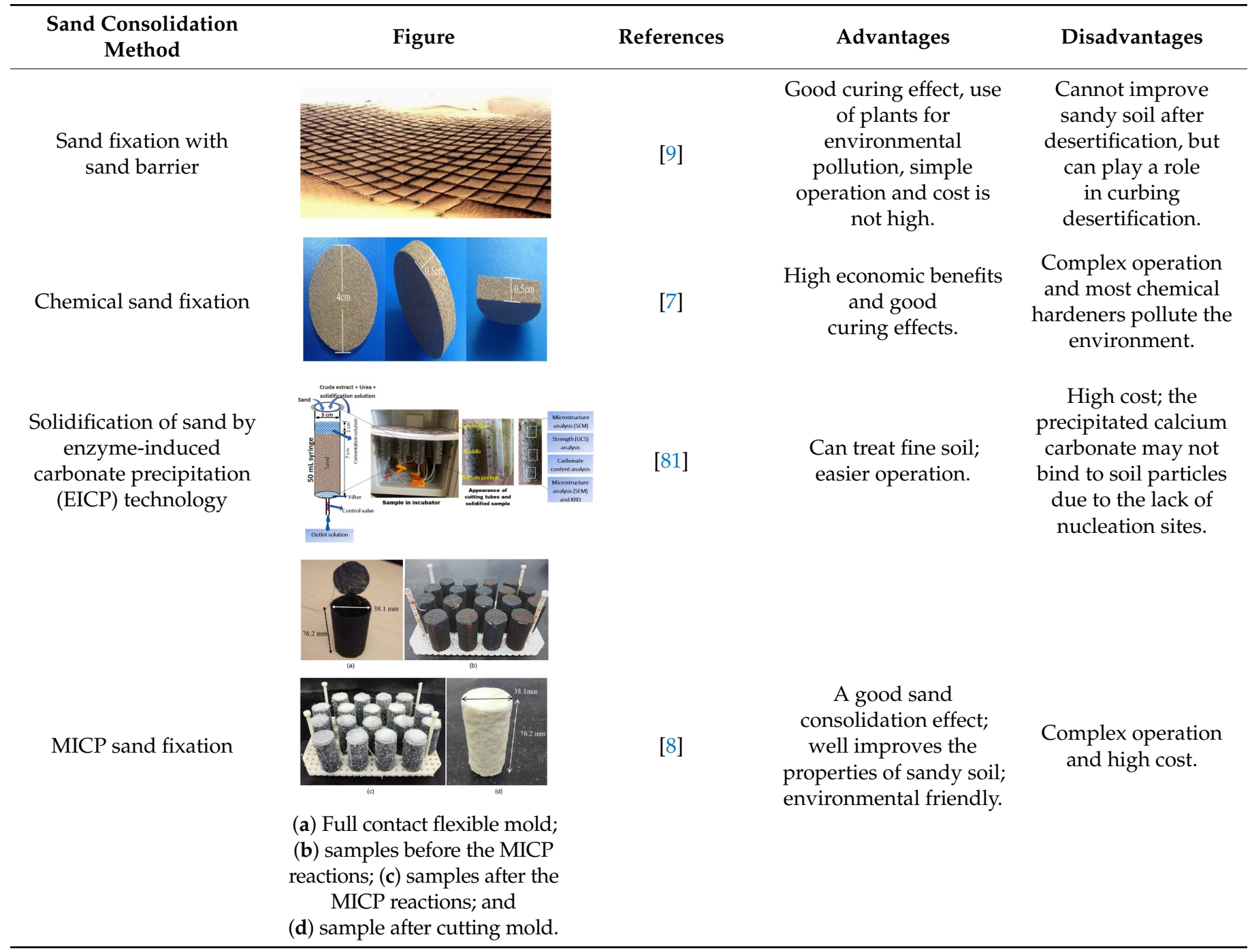

\section{Microbial Sources of Solidified Sand}

There are two methods of microbially solidifying soil: one is the introduction of exogenous bacterially solidified soil, but as there are plenty of other microbes in the sand, the exogenous bacteria may compete with the existing microbes for nutrients. Therefore, it is necessary to add exogenous bacterial fluid constantly, which results in high cost. The other method is to use urea-producing bacteria existing in sandy soil, not by introducing exogenous bacteria, but by adding cementation solution and nutrients that facilitate the growth of indigenous bacteria. These two sand consolidation methods will affect the size and quantity of the calcium carbonate generated. Gomez et al. [82] found that compared with the calcium carbonate generated by exogenous bacteria, the size and quantity of calcium carbonate crystals generated by indigenous bacteria solidified sand soil were larger and fewer.

\subsection{External Bacteria Solidifying the Sandy Soil}

There have been many studies on introducing exogenous bacteria in order to solidify sandy soil. It is necessary to add cementing fluid to stimulate indigenous bacteria 
to produce calcium carbonate precipitation, and at the same time, introduce exogenous urease-producing bacteria that can enhance the effect of microbial sand consolidation. Bernardi et al. [83] solidified sand with Sporosarcina paseurii, and the minimum porosity ratio of sand was 0.5 . When the concentration of urea was $200 \mathrm{mM}$, the concentration of calcium chloride was $100 \mathrm{mM}$, and the $\mathrm{OD}_{600}$ of the bacterial solution was one, the porosity ratio of sand samples after 28 days of treatment decreased to about 0.33 , because the generated calcium carbonate was blocked in the original gaps in the sandy soil. Nafisi et al. [84] compared the effect of curing silica sand with Sporosarcina pasteurii and urease powder. They found that compared with curing silica sand with urease powder, curing silica sand with Sporosarcina pasteurii generated more calcium carbonate, and the shear strength of the solidified sand sample was greater. However, Ahenkorah et al. [85] compared the mechanical properties of sand samples solidified by MICP and EICP, and found that the splitting tensile strength of sand treated by EICP is higher than that of MICP. Cheng et al. [86] solidified the sand by a single-phase injection of low $\mathrm{pH}$ integrated solution into the sand, and mixed $\mathrm{OD}_{600}$ of 4.2 Bacillus sp. with $1 \mathrm{M}$ urea-calcium chloride solution to form an integrated solution. The $\mathrm{pH}$ of the solution was adjusted to four, and the rate of solution transmission was $1 \mathrm{~L} / \mathrm{h}$. After six times of treatments, the compressive strength of the sand sample reached $2.5 \mathrm{MPa}$.

Exogenous bacteria are also used in curing sand in the sea; Cheng et al. [49] proposed an innovative method of biological sand fixation method, which, without introducing $\mathrm{Ca}^{2+}$, the $\mathrm{Ca}^{2+}$ contained in seawater was used as the sole source of calcium, and then Bacillus sp. was introduced to solidify the sand in the seawater environment. The experimental results showed the feasibility of using $\mathrm{Ca}^{2+}$ from seawater to solidify sandy soil, including that seawater can be used many times and is beneficial to improving the mechanical performance of sandy soil. The use of MICP technology for biocementation in the seawater environment provides a potential method for land reclamation. $\mathrm{Xu}$ et al. [87] proposed an experimental scheme similar to that of Cheng, using no additional introduced exogenous $\mathrm{Ca}^{2+}$, and only using $\mathrm{Ca}^{2+}$ from the fly ash of municipal incineration waste. The ratio of the fly ash to $S$. pasteurii bacterial solution was $1 \mathrm{~kg}: 0.3 \mathrm{~L}$. At $20^{\circ} \mathrm{C}$, humidity is not less than $95 \%$ for the 7 days curing experiment environment. The results show that the leaching rate of heavy metals decreases obviously after the solidification of fly ash, and the compressive strength increases by nearly $40 \%$ compared with that before the solidification. Wang et al. [88] used MICP technology to reduce the wind erosion rate of sandy soil. Their results showed that the wind erosion rate of untreated sandy soil was $10.23 \%$, but when MICP treatment times were more than three times, the wind erosion rate of sandy soil dropped below $0.4 \%$. Wind erosion rate is the ratio of the mass of the remaining sand that has been blown by the wind to the mass of the original sand that has not been blown.

Using exogenous bacteria to solidify sand requires the addition of bacterial liquid and cementation solution. The newly added exogenous bacteria will compete with the bacteria inside the sandy soil, so the bacterial solution needs to be added at intervals to ensure that the exogenous bacteria survive. Many studies have shown that exogenous bacteria can solidify soil, but by adding exogenous bacteria to the sand, it can be found that there is a lot of precipitation generated at the filling mouth, and the sediment distribution in the sand is not uniform. Moreover, the introduction of exogenous bacteria may not be conducive to the protection of ancient buildings, such as the reinforcement of the surface of ancient buildings and the repair of cracks, etc., the introduction of exogenous bacteria may destroy the dynamic balance of the bacterial community inside the original ancient buildings, and may cause secondary damage to the ancient buildings [89]. Therefore, solving these problems can be the direction of future research.

\subsection{Solidification of Sandy Soil by Indigenous Bacteria}

The indigenous bacteria themselves exist in the sandy soil and have strong adaptability to the environment. There are two ways to solidify sandy soil with indigenous bacteria. The first is to screen out indigenous bacteria from the soil for culture and then add the 
bacterial culture solution and cementation solution in the sand; the other is to directly add nutrients for the in-situ culture of bacteria and then add the cementation solution to the sand. The utilization of indigenous bacteria is economical and effective, causes less environmental pollution, and may lead to the uniform distribution of induced $\mathrm{CaCO}_{3}$ precipitation [90]. The introduction of indigenous bacteria can be used for the conservation of ancient buildings. It can be seen from Figure 11 that the untreated surface of ancient buildings in the $\mathrm{MgSO}_{4}$ solution has a fast dissolving rate, and after dealing with the indigenous bacteria on the ancient building surface, the surface of the ancient building was not obviously dissolved under $\mathrm{MgSO}_{4}$ solution erosion, indicating that indigenous bacteria carried out on the ancient surface treatment can reduce the salt chemical weathering and thus protect the surface of ancient buildings [89].
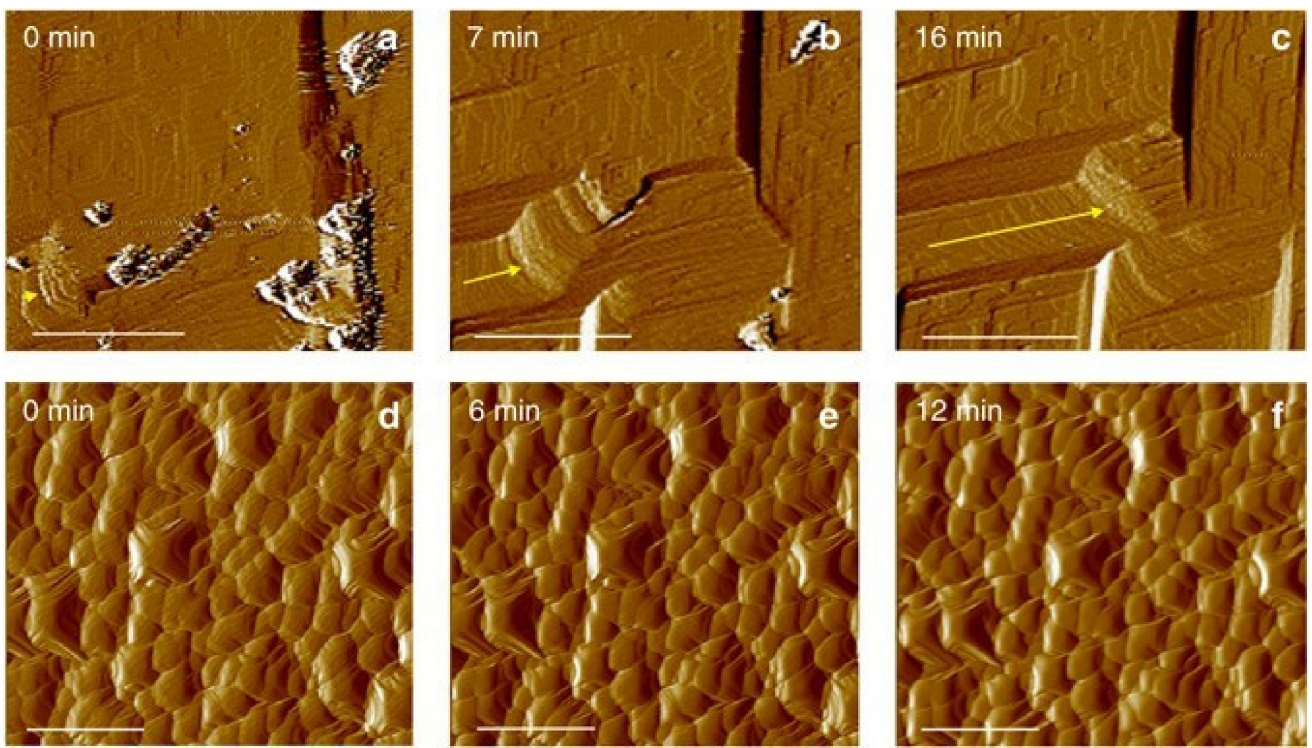

Figure 11. AFM image of the calcite surface over time after exposing the ancient building surface to MgSO4 solution. (a-c) Untreated; (d-f) Indigenous bacteria-treated [89].

Cheng et al. [91] enriched urease bacteria in soil and added the cementation solution to the soil for in-situ curing experiments. The results showed that in-situ curing does not cause surface blockage on the $1 \mathrm{~m}$-high soil column, but the method of injecting the cementation solution should be constantly optimized in order to achieve deeper curing. Burbank et al. [92] found that urease-producing micro-organisms can be isolated in soils lacking urea or a high concentration of ammonia, and these microorganisms could be applied to mineralize the soil and repair the existing cracks in the soil. Kumari et al. [50] reported that MICP could fix $\mathrm{Cd}$ in the soil at low temperatures. E. undae YR10 isolated from the Yangtze River basin near Chongming Island fixed $\mathrm{Cd}$ in farmland soil near Chongming Island at $10^{\circ} \mathrm{C}$ and $25^{\circ} \mathrm{C}$, and then converted $\mathrm{Cd}$ into components in carbonate. Burbank et al. [93] selected the soil with high urease content for microscopic tests and cyclic triaxial shear tests and found that not introducing exogenous bacteria and directly adding mineral solution can induce calcite precipitation, so as to improve the anti-liquefaction ability of sand; this method can achieve greater economic benefits than the addition of exogenous bacteria. Chahal et al. [94] screened and isolated urease-producing bacteria from alkaline soil to repair cracks formed in concrete and improve the life of the concrete. Gowthaman et al. [53] successfully isolated Lysinibacillus xylanilyticus, a bacterium from the sub-arctic region, which can produce urease at low temperatures, and successfully applied this bacterium to a slope-improvement project. The greater the urease activity of urease-producing bacteria, the better its effect in solidifying sand. Wang et al. [95] screened urea-producing bacteria from beach sand and studied the effects of different media and urea concentrations on bacterial urease activity. The experiment results showed that 
nitrogen-rich composite media such as YE and NB increase bacterial urease activity, and urease activity at $100 \mathrm{mM}$ concentration is highly efficient. Khan et al. [96] isolated a urease bacterium named Parahodobacter sp. from a beach of coral sand. Parahodobacter sp. was used to cure the coral sand for 28 days, and the compressive strength of the solidified coral sand reached $20 \mathrm{MPa}$. Oualha et al. [97] screened and isolated two strains of indigenous bacteria B. cereus from Qatari soil, namely QBB4 and QBB5. Both of these strains can solidify Qatari soil with a high $\mathrm{pH}$ and in a poor environment, and in a field experiment, the $\mathrm{CaCO}_{3}$ content generated by soil solidified with QBB4 increased by $16.2 \%$ compared with the original soil. Song et al. [98] isolated Staphylococcus succinusJ3 with high urease activity from the soil in a mining area and showed that the application of coal ash in a bacterially mineralized mining area could play a positive role. After solidification, the maximum wind speed of coal ash reached $45.5 \mathrm{~m} / \mathrm{s}$, and the maximum wind pressure reached $912 \mathrm{kPa}$. For the first time, Imran et al. [99] isolated indigenous urea-lytic bacteria from coastal erosion areas in Greece and showed that $\mathrm{CaCO}_{3}$ could be generated, effectively protecting the coast from erosion. Chu et al. [100] isolated urease-producing bacterium (UPB) VS1 from tropical beaches and found that the solution of urea and calcium chloride added was lower than the sand surface, and calcium carbonate is evenly distributed in the sand. The solution of urea and calcium chloride added was higher than the sand surface, and the resulting calcium carbonate formed a solid shell on the sand surface.

\section{Models for Predicting the Curing Process of MICP in the Field}

The technology of microbial solidification of sand is relatively mature in the laboratory. For example, Phillips et al. [101] repaired sandstone fractures using two grouting methods and the experiment showed that multiple grouting methods promote the even distribution of $\mathrm{CaCO}_{3}$ deposit in sandstone along the inflow direction. However, excessive repeated treatment leads to deposition blockage near the injection point [102]. Microbial solidification of sand has also been used in the field. Cuthbert et al. [103] applied MICP technology to fractured rocks and showed that when bacterial fluid and urea are simultaneously injected into fractured rocks, the addition of $\mathrm{CaCl}_{2}$ solution promotes the formation of $\mathrm{CaCO}_{3}$ precipitation to repair cracks, thus significantly reducing the permeability of rocks.

However, field tests need to overcome difficulties caused by many environmental factors and are very expensive [104]. Therefore, field tests are rare. Harkes et al. [105] used the two-stage method of adding bacterial solution and fixation solution in order to make the calcium carbonate generated by MICP evenly distributed in the sand, but the operation is complicated and the economic cost is high. Due to the complexity of the natural environment, some phenomena are difficult to explain. Ohan et al. [106] found that after applying MICP, the $\mathrm{pH}$ value of groundwater decreased, which contradicted the normal $\mathrm{pH}$ value increase.

The researchers found that models could be used to better analyze the dynamic changes and reaction mechanisms of the MICP process. A good model can predict the mechanical properties of MICP solidified sand samples and is helpful for the engineering design [107]. Table 4 lists some models that predict the curing process of MICP. Fauriel et al. [108] proposed a prediction model of the microbial grouting response based on the changes in porosity, permeability and density of soil after microbial grouting. Connolly et al. [109] introduced urease genes into P. aeruginosa AH298 and E. coli AF504gfp to construct two urease strains of Pseudomonas aeruginosa MJK1 and Escherichia coli MJK2 that had a characteristic of expressing green fluorescent protein (GFP), and used the Gompertz function to model the bacterial population density. It was found that the urealytic rate of the two strains was not high, Escherichia coli MJK2 grew faster, and Pseudomonas aeruginosa MJK1 had a higher urealytic rate. Gai et al. [110] established a model to evaluate the mechanical properties of MICP-solidified sandy soil, which clearly reflects changes in the mechanical properties of solidified sand soil, and the analysis of model parameters and the law of mechanical properties change are helpful to understand the process of MICP solidification. The results showed that mechanical properties are related to $\mathrm{CaCO}_{3}$ 
content. Wang et al. [111] established a biochemical-hydraulic model, which proposes the concept of porosity to reflect the change of permeability. Their results showed that the pore structure has an important influence on the curing rate, the maximum urease rate has an indispensable influence on the hydraulic response of MICP, and the MICP reaction rate is influenced by the concentration of the bacterial and cementation solutions. Martinez et al. [112] proposed a biological reaction migration model, which coupled UCODE-2005 with TOUGHREACT sequence, and its practicability was confirmed in the MICP prediction experiment. TOUGHREACT numerical simulation program was used to reflect the reaction rate of urea hydrolysis and $\mathrm{CaCO}_{3}$ generation in the MICP process. UCODE-2005 model was used to correct and verify the MICP experimental data. The results showed that the actual experimental results are close to the predicted data in the half-meter sand column experiment and dynamic changes in the MICP process can be seen.

Table 4. Models for predicting the curing process of MICP.

\begin{tabular}{|c|c|c|}
\hline Model Names & The Role of Models & References, Year \\
\hline Aquifer conceptual model & $\begin{array}{c}\text { Finding that the sedimentation rate } \\
\text { of calcite is closely related to the } \\
\text { hydrolysis rate of urea }\end{array}$ & [113], 2005 \\
\hline $\begin{array}{l}\text { A three-dimensional (3D) discrete } \\
\text { element method (DEM)-based } \\
\text { numerical model }\end{array}$ & $\begin{array}{l}\text { Simulating the macroscopic } \\
\text { mechanical properties of } \mathrm{CaCO}_{3} \\
\text { sediment-solidified sandy soil } \\
\text { induced by micro-organisms under } \\
\text { the condition of no triaxial } \\
\text { compression of the drainage system }\end{array}$ & [114], 2019 \\
\hline $\begin{array}{l}\text { A loose sandstone numerical } \\
\text { model based on a } \\
\text { one-dimensional advective } \\
\text { dispersion model }\end{array}$ & $\begin{array}{l}\text { Predicting the movement of } \\
\text { micro-organisms in soil and rock }\end{array}$ & [115], 2014 \\
\hline A pore-scale network model & $\begin{array}{l}\text { Simulating the } \mathrm{CaCO}_{3} \text { precipitation } \\
\text { process and the influence of } \\
\text { different operations on } \\
\mathrm{CaCO}_{3} \text { precipitation }\end{array}$ & [116], 2016 \\
\hline $\begin{array}{l}\text { Thermal conductivity } \\
\text { predictive models }\end{array}$ & $\begin{array}{l}\text { Predicting the thermal } \\
\text { conductivities of } \\
\text { MICP-treated sands }\end{array}$ & [117], 2020 \\
\hline $\begin{array}{l}\text { A small repeated five-point } \\
\text { treatment model }\end{array}$ & $\begin{array}{l}\text { Predicting solidification treatment } \\
\text { in large-scale field experiments }\end{array}$ & [118], 2014 \\
\hline The biogrouting foam model & $\begin{array}{l}\text { Simulating key solidification } \\
\text { processes such as on-site bacterial } \\
\text { solution perfusion and adhesion } \\
\text { and urea hydrolysis }\end{array}$ & [119], 2019 \\
\hline
\end{tabular}

The solidification effect and mechanical properties of MICP can be simulated by the model. Before the large-scale outdoor experiment, model analysis of the existing laboratoryscale experimental data can be carried out to predict the results of the large-scale outdoor experiment. The combination of model analysis and laboratory data is conducive to the smooth implementation of large-scale field experiments [27,120]. At present, researchers have established many models, and each model has its own role. In the future, multiple models can be combined to improve the accuracy of the model prediction.

\section{Factors Affecting Microbial Solidification of Sandy Soil}

The effect of microbial solidification of sandy soil is influenced by a variety of factors, including the concentration of the cementation solution, the concentration of culture liquid, temperature, calcium source and $\mathrm{pH}$ value. Before large-scale experiments, the 
effects of different factors on the solidification effect should be studied to optimize the experimental conditions and determine the optimal solidification conditions. Under the same conditions, the curing effect of the same bacteria on different sandy soil is different. Table 5 shows the optimal conditions for microbial solidification determined by researchers when conducting MICP.

Table 5. Results on the optimal curing conditions of urease-producing bacteria.

\begin{tabular}{|c|c|c|c|c|c|}
\hline \multirow{2}{*}{ Microbe Name } & \multicolumn{4}{|c|}{ Optimum Curing Condition } & \multirow{2}{*}{ Reference, Year } \\
\hline & $\begin{array}{l}\text { Microbial } \\
\text { Concentration }\end{array}$ & $\begin{array}{l}\text { The Concentration of } \\
\text { Cementation Solution }\end{array}$ & Temperature & Cure Time & \\
\hline Sporosarcina pasteurii & $1 \times 10^{7}$ cells $/ \mathrm{mL}$ & $0.5 \mathrm{M}$ urea- $\mathrm{CaCl}_{2}$ & $20^{\circ} \mathrm{C}$ & 16 days & [121], 2012 \\
\hline B. megaterium & $1 \times 10^{8} \mathrm{cfu} / \mathrm{mL}$ & $0.5 \mathrm{M}$ urea- $\mathrm{CaCl}_{2}$ & $22-27^{\circ} \mathrm{C}$ & $48 \mathrm{~h}$ & [122], 2014 \\
\hline Parahodobacter sp. & $10^{9} \mathrm{cfu} / \mathrm{mL}$ & $0.5 \mathrm{M}$ urea- $\mathrm{CaCl}_{2}$ & $30^{\circ} \mathrm{C}$ & 21 days & [96], 2015 \\
\hline Sporosarcina pasteurii & $\mathrm{OD}_{600}=4$ & $\begin{array}{l}3.0 \mathrm{M} \text { urea, } \\
1.5 \mathrm{M} \mathrm{CaCl}_{2}\end{array}$ & $30^{\circ} \mathrm{C}$ & 21 days & [123], 2016 \\
\hline Staphylococcus succinu & $\mathrm{OD}_{600}=0.7$ & $40 \mathrm{mmol} \mathrm{Ca}^{2+}, 6 \%(w / w)$ urea & $30^{\circ} \mathrm{C}$ & 35 days & [98], 2019 \\
\hline S. aquimarina & $12.8 \times 10^{9}$ cells $/ \mathrm{ml}$ & $0 \cdot 25 \mathrm{M}$ urea, $2 \mathrm{M} \mathrm{CaCl}_{2}$ & - & - & [124], 2018 \\
\hline S. pasteurii & $9 \times 10^{9}$ cells $/ \mathrm{ml}$ & $1 \mathrm{M}$ urea, $2 \mathrm{M} \mathrm{CaCl}_{2}$ & - & - & \\
\hline Pararhodobactersp. & $\frac{-}{1 \times 10^{8}}$ & $0.5 \mathrm{M} \mathrm{CaCl}_{2}$ & $25^{\circ} \mathrm{C}$ & 14 days & $\begin{array}{c}{[44], 2018} \\
{[125] 2020}\end{array}$ \\
\hline Sporosarcina pasteurii & $1 \times 10^{8}$ cells $/ \mathrm{mL}$ & $50 \mathrm{mM} \mathrm{Ca}^{2+}$ & - & - & {$[125], 2020$} \\
\hline
\end{tabular}

\subsection{Concentration of Cementation Solution}

To induce $\mathrm{CaCO}_{3}$ precipitation with micro-organisms, cementation solution needs to be added. Cementation solution refers to the calcium source and urea solution. Different concentrations of cementation solution affect the compressive strength and permeability of sandy soil after cementation. In addition, the size and distribution of calcium carbonate generated by different concentrations of cementation solution in sandy soil are also different. Al Qabany et al. [121] studied the influence of different cementing fluid concentrations on solidified sand and found that the size of calcium carbonate particles generated after the treatment of $0.25 \mathrm{M}$ urea-CaCl 2 was similar and distributed evenly, the size of calcium carbonate particles generated after the treatment of $0.5 \mathrm{M}$ urea- $\mathrm{CaCl}_{2}$ was different and distributed unevenly, and the size of calcium carbonate generated after treatment with $1 \mathrm{M}$ urea- $\mathrm{CaCl}_{2}$ was large and distributed unevenly. In a word, as the concentration of cementation solution increased, the surface strength of the solidified sample increased and more $\mathrm{CaCO}_{3}$ content was precipitated. However, there is no correlation between surface strength and $\mathrm{CaCO}_{3}$ content [126]. Too low a concentration of $\mathrm{Ca}^{2+}$ is not conducive to the formation of $\mathrm{CaCO}_{3}$, while too high a concentration of $\mathrm{Ca}^{2+}$ may inhibit the urease activity of micro-organisms and affect the formation of $\mathrm{CaCO}_{3}$ precipitation [127]. The concentration of urea can also affect the effect of microorganism sand fixation; properly increasing the concentration of urea will increase the production of calcium carbonate [128]. $\mathrm{Li}$ et al. [129] found that as the concentration of the solution of solidified aeolian sand increased, the $\mathrm{CaCO}_{3}$ content increased, leading to increased sand density. Qabany et al. [130] used a $0.1-1 \mathrm{~mol} / \mathrm{L}$ urea- $\mathrm{CaCl}_{2}$ solution and $10^{7}$ cells $/ \mathrm{mL}$ Sporosarcina pasteurii bacterial solution to cement sandy soil, and found that sandy soil treated with a high concentration of cementation solution had lower permeability than that treated with a low concentration of cementation solution, but the low concentration of cementation solution which was repeatedly fed into the resulting sediment was more uniform. Ng Wei Soon et al. [122] used the solution of $B$. megaterium and solution of urea-calcium chloride to solidify residual soil with a maximum dry density of $1688.5 \mathrm{~kg} / \mathrm{m}^{3}$, and found that when the concentration of urea and calcium chloride were both $0.5 \mathrm{~mol} / \mathrm{L}$, the concentration of $\mathrm{B}$. megaterium was $1 \times 10^{8} \mathrm{cfu} / \mathrm{mL}$, and the flow pressure of the cementation solution was $1.1 \mathrm{bar}$. The treatment time was $48 \mathrm{~h}$, the engineering properties of the residual soil were improved the most; the shear strength of the cured sand was increased by $69 \%$. Their microbial solidification experiment was carried out on the interaction between the cementation solution and the bacterial solution, and the concentrations of the two affected and restricted each other. 
Mujah et al. [131] used the solution of Bacillus sp. and solution of urea-calcium chloride dehydrate to solidify silica sand with a maximum dry density of $16.3 \mathrm{kN} / \mathrm{m}^{3}$, and found that the optimal solidification scheme was $32 \mathrm{U} / \mathrm{mL}$ urease concentration of Bacillus sp. bacterial solution and $0.25 \mathrm{M}$ concentration of urea-calcium chloride dehydrate, and this could form rhombic calcite of a relatively large size. This crystal type of $\mathrm{CaCO}_{3}$ can not only significantly improve the strength and stiffness of soil, but also maintain the permeability of soil samples. Whitaker et al. [132] found that $S$. ureae had a stronger curing capacity than S. pasteurii, which has been widely studied. When the researchers used $S$. ureae bacteria solution and added $0.5 \mathrm{M}$ cementation solution, the direct shear strength of the solidified sandy soil increased from $15.77 \mathrm{kPa}$ before solidification to $135.80 \mathrm{kPa}$. Chen et al. [133] used a strain of bacillus isolated from a mine tailing soil to solidify sandy soil, and found that when a cementation solution consisting of $15 \mathrm{mM} \mathrm{Ca}^{2+}$ and $20 \mathrm{~g} / \mathrm{L}$ urea was added to bacterial liquid with an $\mathrm{OD}_{600}$ value of 0.4 , the solidification effect was the best and the cost was the lowest. Jiang et al. [134] used $1.91 \times 10^{8}$ cells $/ \mathrm{mL}$ of Sporosarcina pasteurii to improve the erosion resistance of silica sand with particle sizes ranging from 100 to $500 \mu \mathrm{m}$, and showed that the addition of $0.2 \mathrm{M}$ and $1.0 \mathrm{M}$ concentrations of urea- $\mathrm{CaCl}_{2}$ solution improved the erosion resistance of the slope, while the addition of $2.0 \mathrm{M}$ concentration of urea- $\mathrm{CaCl}_{2}$ solution did not improve the erosion resistance of the slope.

In summary, the concentration of cementation solution will affect the size and content of calcium carbonate and its distribution uniformity in the sand. Most studies optimized the concentration of urea solution and calcium ion as the overall concentration of cementation solution, but calcium ion concentration and urea concentration both affect the effect of microbial sand consolidation, so the concentration of urea and calcium ions in cementation solution can be optimized, respectively, in the future.

\subsection{Bacterial Concentration}

In the process of the introduction of exogenous bacteria to solidify soil, a different concentration of bacterial solution has a different effect on the curing effect. The determination of the optimum microbial concentration is beneficial to improve the performance of cured samples. The optimum concentration of the same bacteria needed to irrigate sand from different sources was different, and the optimum concentration of bacteria solidified by the same source sand was also different.

B. pasteurii is usually used as an exobacterium, and Chahal et al. [135] determined through experiments that the optimal concentration of $B$. pasteurii bacterial solution is $10^{5}$ cells $/ \mathrm{mL}$. After 91 days of curing, the compressive strength of concrete was significantly improved compared with that of untreated concrete, with an increase of $44 \mathrm{MPa}$. The increase in compressive strength of the solidified samples was due to the increase in calcium carbonate precipitation induced by bacteria. The concentration of the bacterial solution will affect the rate of calcium carbonate precipitation. Wen et al. [136] used Sporosarcina pasteurii and urease to cure sandy soil. Figure 12 [136] shows SEM images of $\mathrm{CaCO}_{3}$ after treatment with different concentrations of bacterial liquid. As can be seen from Figure 12, when the OD600 of the bacterial solution was 0.1 , flower-like crystals were precipitated at $168 \mathrm{~h}$, while when the OD600 of the bacterial solution exceeded 0.1, flower-like crystals were precipitated at $72 \mathrm{~h}$. Andalib et al. [137] found that the compressive strength and flexural strength of a bacterial concrete sample made of $30 \times 10^{5} \mathrm{cfu} / \mathrm{mL}$ Bacillus megaterium were the largest. When the bacterial concentration exceeded $30 \times 10^{5} \mathrm{cfu} / \mathrm{mL}$, the compressive strength and flexural strength of the sample decreased. 

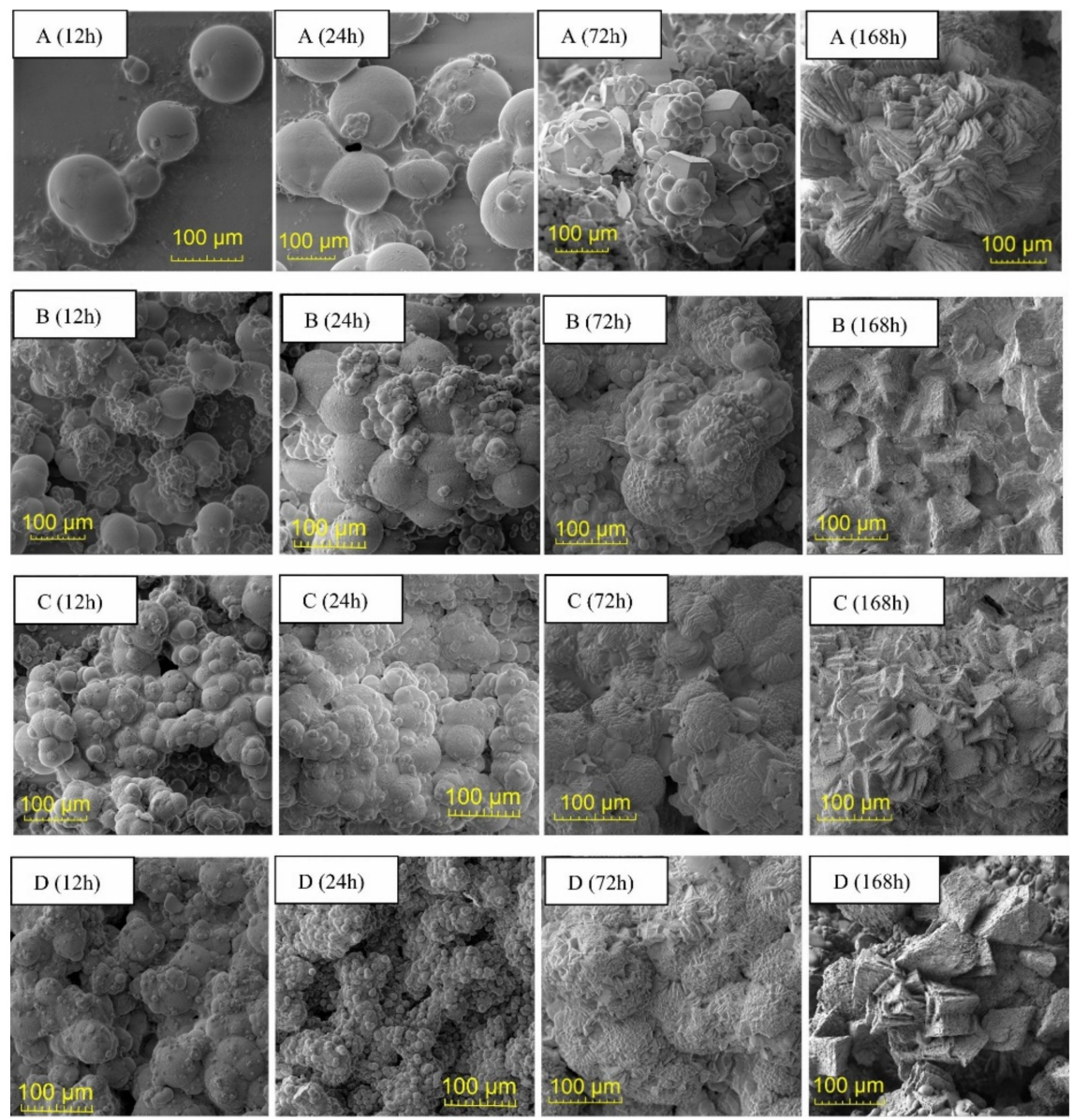

Figure 12. SEM images of $\mathrm{CaCO}_{3}$ treated with different concentrations of bacterial solution. (A) $\mathrm{OD}_{600}=0.1 ;(\mathbf{B}) \mathrm{OD}_{600}=0.3 ;(\mathbf{C}) \mathrm{OD6}_{00}=0.6 ;(\mathbf{D}) \mathrm{OD}_{600}=1.0$ [136].

In summary, the concentration of the bacterial liquid will affect the sedimentation rate and crystal formation of calcium carbonate [136]. The concentration of bacteria solution is an important factor affecting the effect of microbial sand consolidation. Optimizing the concentration of bacteria solution is beneficial to improving the mechanical properties of sand. In the future, the economical medium composition that can achieve the optimal concentration of bacteria solution can be found to reduce the cost when achieving the same sand fixation effect.

\subsection{Temperature}

The temperature will affect the urease activity of urease bacteria, bacteria growth ability, and the production of calcium carbonate. Therefore, temperature control is very important in the application of microbial sand fixation. The calcite precipitated at different temperatures has different shapes [31]. The optimal temperature for urease-catalyzed hydrolysis of urea is generally between $20^{\circ} \mathrm{C}$ and $37^{\circ} \mathrm{C}$. Figure 13 [138] shows the effect of temperature on the urease activity of some urease-producing bacteria. It can be seen from Figure 13 that the urease activity of these five strains was the highest when cultured at $25-30{ }^{\circ} \mathrm{C}$. However, Fujita et al. [139] isolated Pararhodobacter sp. SO1 from nearby Okinawa, Japan. This bacterium showed the highest urease activity under $60^{\circ} \mathrm{C}$ environment, and the urease activity decreased over $60^{\circ} \mathrm{C}$. The optimal temperature conditions for the formation of $\mathrm{CaCO}_{3}$ from urea catalyzed by different urease-producing bacteria are also different [28]. Kim et al. [140] found that the optimal induced calcite precipitation temperature of urease-producing bacteria B. pasteurii was $30^{\circ} \mathrm{C}$, and Imran et al. [141] found that for urease-producing bacteria Pararhodobacter sp., the optimal $\mathrm{CaCO}_{3}$ generation temperature was $35^{\circ} \mathrm{C}$. Deng et al. [142] found that when the temperature of Sporosarcina 
pasteurii was $10^{\circ} \mathrm{C}$, the bacterial $\mathrm{OD}_{600}$ was less than 1.0 , which reduces the effect of the solidified sand. The optimal temperature for Sporosarcina pasteurii growth was $30-35^{\circ} \mathrm{C}$. Cheng et al. [143] simulated the solidification effect in cold, tropical and arid regions, and selected three temperatures, $4^{\circ} \mathrm{C}, 25^{\circ} \mathrm{C}$ and $50^{\circ} \mathrm{C}$, for their experiment. The results showed that compressive strength after curing increases with the increase in the precipitated $\mathrm{CaCO}_{3}$ content at any temperature. The optimal curing temperature is $25^{\circ} \mathrm{C}$. The size of a single calcite crystal cured at $25^{\circ} \mathrm{C}$ is about 10 times that of a single calcite crystal cured at $4{ }^{\circ} \mathrm{C}$ or $50^{\circ} \mathrm{C}$. Large-size calcium carbonate crystals can effectively fill the gap of the sand, which is beneficial to increase the strength of the solidified sand.

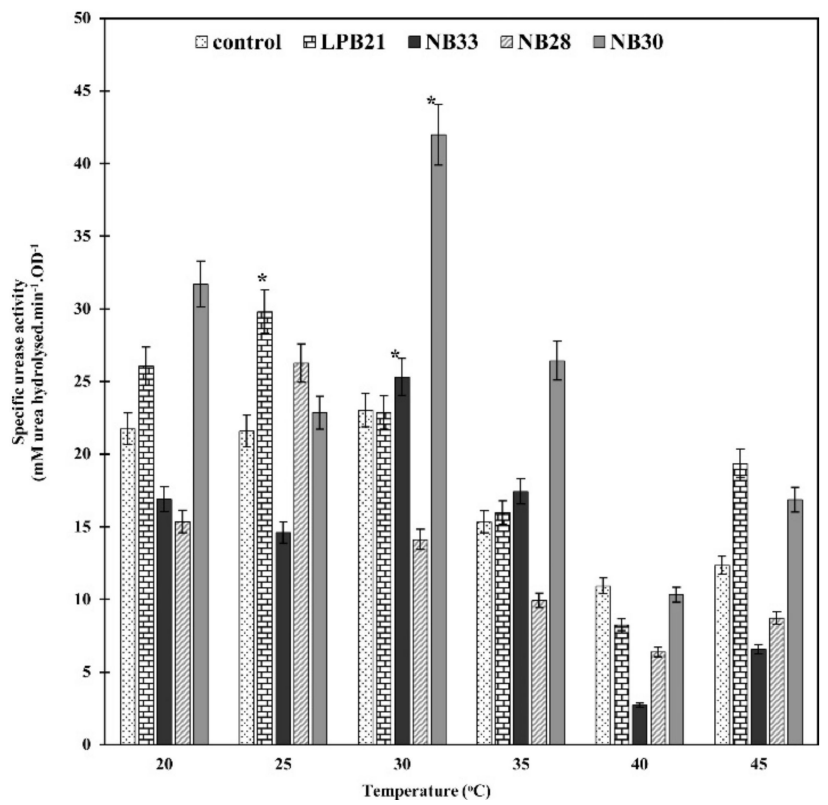

Figure 13. Effect of temperature on urease activity of urease-producing bacteria. Control: S. pasteurii DSM 33; LPB21: closest match Sporosarcina pasteurii fwzy14; NB33: closest match Sporosarcina pasteurii WJ-4; NB28: closest match Sporosarcina pasteurii WJ-5; NB30: closest match Sporosarcina pasteurii fwzy14. Significance level was set to $0.05\left(^{*}\right)$ [138].

Temperature affects the permeability of the oil reservoir by urease solidification, but the solidification effect of temperature on oil reservoirs does not have a single cause, and is also affected by urease concentration. With the increase in temperature, the consolidation capacity of a high-concentration urease solution is significantly improved and the permeability is constantly enhanced, while a low-concentration urease solution shows little change in permeability with the increase in temperature [17]. In places with too high or too low temperatures, the growth of some micro-organisms is inhibited, posing a challenge for sand consolidation. Suitable curing sites should be selected according to the growth characteristics of the micro-organisms.

In summary, the culture temperature of bacteria will affect the growth ability and urease activity of bacteria, and the urease activity of bacteria will affect the speed of urea decomposition by bacteria, thus leading to the rate of calcium carbonate precipitation MICP reaction temperature influencing the crystal shape and size of calcium carbonate. Therefore, culture temperature and MICP reaction temperature are important factors affecting the MICP effect. At present, there are few studies on the effect of MICP reaction temperature on microbial sand fixation. Next, the influence of different reaction temperatures on microbial sand fixation should be focused on.

\section{4. $p H$ Value}

Urease-producing bacteria hydrolyze urea and increase the $\mathrm{pH}$ value, and when the $\mathrm{pH}$ reaches a certain value, the urease activity is higher, which is conducive to the 
generation of $\mathrm{CaCO}_{3}$ in the MICP process. The initial $\mathrm{pH}$ of the medium can affect the urease activity of the urease-producing bacteria. Figure 14 [138] and Figure 15 [144] showed the effect of the initial medium $\mathrm{pH}$ on the urease activity of some urease-producing bacteria. The results in Figure 14 showed that the optimal initial medium $\mathrm{pH}$ of these urea-producing bacteria was 6.5-8, and the results in Figure 15 showed that the optimal initial medium $\mathrm{pH}$ of the isolated urea-producing bacteria was 10. Wu et al. [145] found that when the $\mathrm{pH}$ of the culture medium was eight, the urease activity of $B$. cereus CS1 reached the highest value. Alonso et al. [146] found that the urease activity of the screened ureolytic bacterial strains reached the highest value when the $\mathrm{pH}$ was eight. Microbial solidification requires the addition of bacterial solution and cementation solution to sandy soil. Kim et al. [140] found that the optimal solidification condition for Staphylococcus saprophyticus and Sporosarcina pasteurii was when the $\mathrm{pH}$ of the cementation solution was seven.

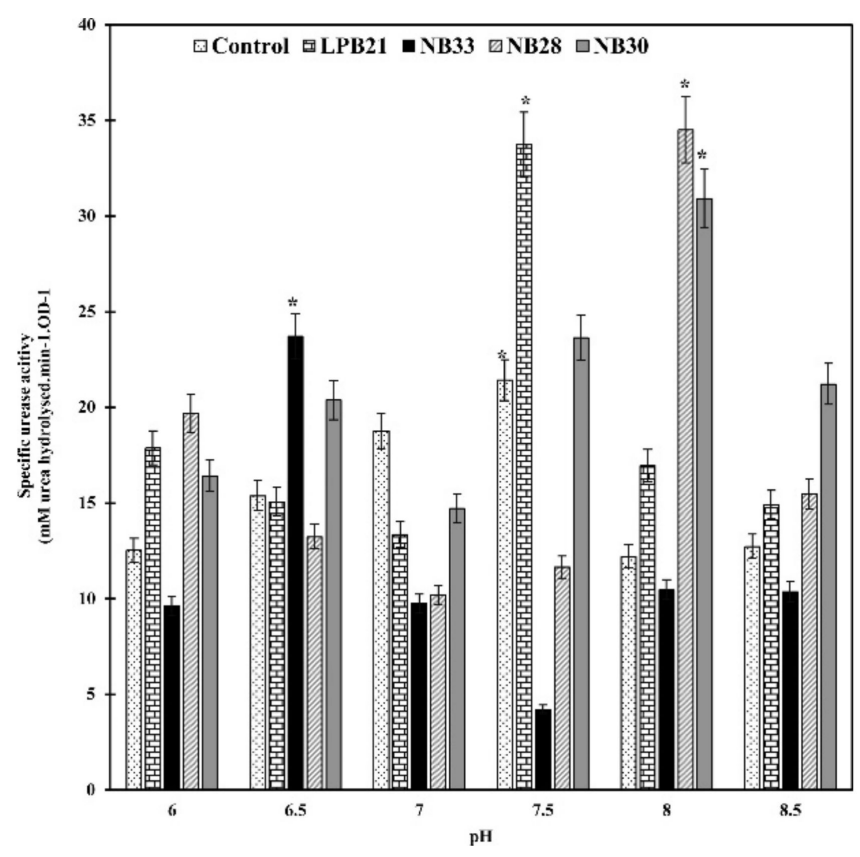

Figure 14. Effect of different initial medium $\mathrm{pH}$ on urease activity. Control: S. pasteurii DSM 33; LPB21: closest match Sporosarcina pasteurii fwzy14; NB33: closest match Sporosarcina pasteurii WJ-4; NB28: closest match Sporosarcina pasteurii WJ-5; NB30: closest match Sporosarcina pasteurii fwzy14. Significance level was set to $0.05\left(^{*}\right)[138]$.

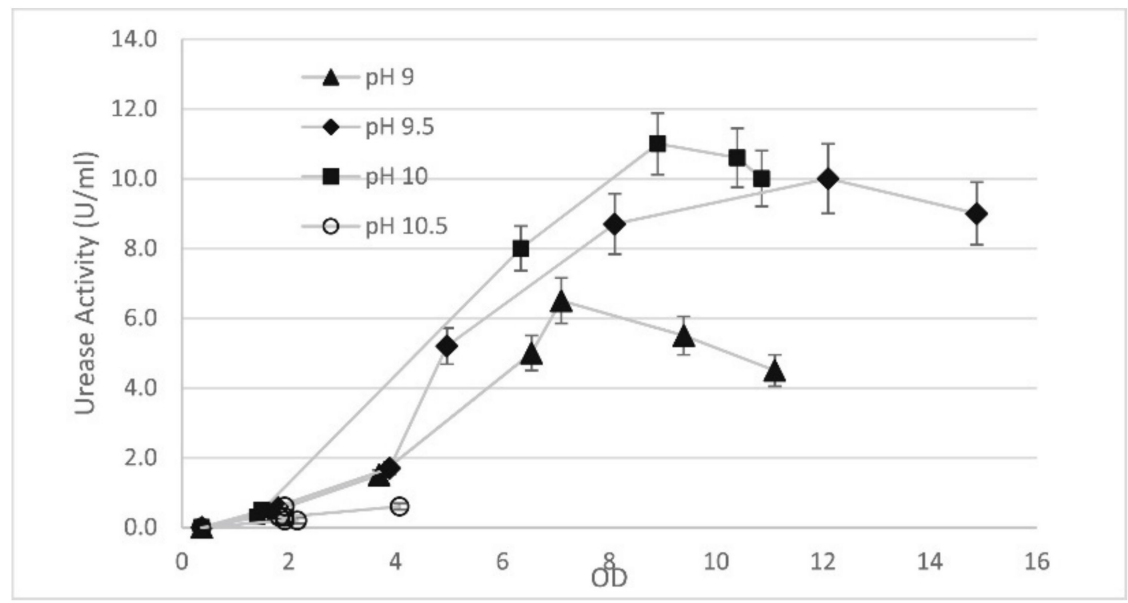

Figure 15. Relationship between urease activity and bacterial concentration under different initial pH mediums [144]. 
The $\mathrm{pH}$ value has an effect on the activity of functional groups, metal ions, and hydride binding sites, which is an important factor affecting the ability of MICP to remove metal ions from sandy soil. Zhao et al. [147] isolated urease bacteria GZ-22 from mining soil and used this bacterium to remove $\mathrm{Cd}^{2+}$. When the $\mathrm{pH}$ of cadmium ion solution was six, the bacteria could precipitate the most $\mathrm{Cd}^{2+}$ precipitation, and the removal efficiency of $\mathrm{Cd}^{2+}$ reached $50.34 \%$.

$\mathrm{pH}$ has the function of regulating the flocculation state of bacterial liquid and cementation solution. Wu et al. [148] prepared the mixed solution, which is composed of bacterial liquid and cementation solution. The mixed solution not adjusted by $\mathrm{pH}$ is flocculated, the flocculation state disappears when $\mathrm{pH}$ is adjusted to $4-5$. The results showed that the flocculation solution without $\mathrm{pH}$ regulation could only effectively treat sand with a particle size of more than $2 \mathrm{~mm}$, while the non-flocculating solution adjusted by $\mathrm{pH}$ can effectively treat sand with any particle size.

In summary, in the growth environment, the $\mathrm{pH}$ value and urease activity of ureaseproducing bacteria will gradually increase. Most of the urease bacteria reported in the literature reached the best urease activity at $\mathrm{pH}$ 8. However, when exogenous bacteria are introduced into the sand, the $\mathrm{pH}$ of exogenous bacteria will decrease, which is not conducive to MICP. The MICP effect is also affected by the $\mathrm{pH}$ value of cementation solution. Therefore, the $\mathrm{pH}$ value of bacteria fluid and cementation solution is an important factor affecting the sand consolidation effect. According to the grouting method, the $\mathrm{pH}$ value of the bacteria liquid and the cementation solution can be independently optimized or the overall $\mathrm{pH}$ value of the bacteria liquid and the cementation solution can be optimized. If the step-by-step grouting method of the bacteria liquid and the cementation solution is adopted, the $\mathrm{pH}$ value of the bacteria liquid and the cementation solution can be independently optimized. If the one-step grouting method is adopted, the overall $\mathrm{pH}$ value of the bacteria liquid and the cementation solution can be optimized.

\subsection{Sources of Calcium}

Many calcium sources are used in the cementation solution to induce microorganisms to produce precipitation, including calcium chloride, calcium acetate, calcium gluconate and calcium lactate [149]. In recent years, researchers have proposed substitutes for commonly-used calcium salts, such as eggshells, seawater, papermaking wastewater, which are more economical and environmentally friendly [150]. Røyne et al. [151] proposed the use of limestone powder as the calcium source for MICP application. First, the limestone powder was dissolved by bacteria AP-004 screened and analyzed from soil near the quarry, and then urease-catalyzed urea hydrolysis was induced by Sporosarcina pasteurii to develop an adhesive, providing a new idea for the source of calcium salt. Choi et al. [152] dissolved limestone powder in acetic acid solution to form calcium ion solution, and found that when using Sporosarcina pasteurii solution with $\mathrm{OD}_{600}$ of $0.8-1.2$ and $0.3 \mathrm{M}$ urea-Ca ${ }^{2+}$ solution to cure sand column, the content of calcium carbonate generated was 8.19\%. Choi et al. [153] used calcium salt produced by mixing eggshells and vinegar in a ratio of 1:8 as the calcium source for biosolidification. The results showed that there was little difference in the effect of sand solidification with calcium salt produced by mixing eggshell and vinegar, and $\mathrm{CaCl}_{2}$ as the calcium source. Liang et al. [154] found that garbage in the kitchen, such as scallop shells, eggshells, and oyster shells, could be used as calcium sources for MICP and play a better role in solidifying sandy soil. Of these, the compressive strength of sandy soil solidified with oyster shells as the calcium source can reach 1454.6 KPa. Liu et al. [155] mixed acetic acid with calcium-containing sandy soil to dissolve the calcium in the sandy soil and compared the calcium dissolved in the sandy soil with a sand column treated with $\mathrm{CaCl}_{2}$. The dry density and compressive strength of the sand column treated with calcium dissolved in sandy soil were higher than those treated with $\mathrm{CaCl}_{2}$, reflecting the feasibility of using calcium dissolved in calcium-containing sand as the calcium source for MICP.

Different researchers have studied the influence of calcium salts on MICP technology and obtained different research results. Pan et al. [156] compared the effects of calcium 
salts $\mathrm{CaCl}_{2}, \mathrm{Ca}\left(\mathrm{NO}_{3}\right)_{2}$, and $\mathrm{Ca}\left(\mathrm{CH}_{3} \mathrm{COO}\right)_{2}$ on Bacillus cereus solidified sand. The results showed that the $\mathrm{CaCO}_{3}$ content precipitated from $\mathrm{CaCl}_{2}$ and $\mathrm{Ca}\left(\mathrm{CH}_{3} \mathrm{COO}\right)_{2}$ as calcium sources were relatively high, while $\mathrm{Ca}\left(\mathrm{NO}_{3}\right)_{2}$ as a calcium source produced more dense and uniform precipitation and greater compressive strength. Zhang et al. [157] compared sandy soil treated with $\mathrm{CaCl}_{2}, \mathrm{Ca}\left(\mathrm{CH}_{3} \mathrm{COO}\right)_{2}$, and $\mathrm{Ca}\left(\mathrm{NO}_{3}\right)_{2}$ as calcium sources and found that the uniaxial compressive strength of mortar treated with $\mathrm{Ca}\left(\mathrm{CH}_{3} \mathrm{COO}\right)_{2}$ was more than twice that of the other two treatments, and the spatial distribution of mortar treated with $\mathrm{Ca}\left(\mathrm{CH}_{3} \mathrm{COO}\right)_{2}$ was more uniform. Abo-El-Enein et al. [158] used S. pasteurii to solidify sandy soil, and $1 \mathrm{M} \mathrm{CaCl}_{2}, \mathrm{Ca}\left(\mathrm{CH}_{3} \mathrm{COO}\right)_{2}, \mathrm{Ca}\left(\mathrm{NO}_{3}\right)_{2}$, and $1 \mathrm{M}$ urea was mixed in the cementation solution, respectively. The test results showed that the samples treated with $\mathrm{CaCl}_{2}$ had more $\mathrm{CaCO}_{3}$ production, higher compressive strength, and lower water absorption than those treated with the other two calcium salts. SEM images showed that the precipitates after solidification of different calcium salts also had different appearances.

To summarize, different calcium salts have different curing effects on sandy soil, so suitable calcium salts should be selected for specific sandy soil. In order to be more economical and environment-friendly, many researchers are actively looking for calcium sources that can replace calcium salts, such as eggshells and seawater. Calcium source is an important component of cementation solution, so finding the best calcium source is beneficial to improving the mechanical properties of solidified sand samples. In the future, more economical calcium salt substitutes can be found, and then the concentration of calcium salt substitutes can be further optimized.

\section{Conclusions and Suggestions for Future Research}

The problem of desertification is becoming more and more serious worldwide. In recent years, microbial sand consolidation technology has become a research hotspot in the field of sand consolidation due to its advantages of solidifying sandy soil, curbing desertification, increasing the permeability of sandy soil, and turning sandy soil into arable land.

The technique of calcium carbonate precipitation induced by micro-organisms has broad application prospects for the solidification of sand and the protection of building materials. The micro-organisms used to solidify sandy soil are derived from urease bacteria in sandy soil or the external environment. Urease-producing bacteria in sandy soil are generally more evenly distributed than the $\mathrm{CaCO}_{3}$ produced by external bacteria. Numerical model analysis of existing laboratory data to simulate the parameters and expected results of large-scale experiments in the field can save costs and contribute to the smooth operation of large-scale experiments.

Many factors affect the microbial solidification of sandy soil, including the cementation solution concentration, bacterial liquid concentration, temperature, $\mathrm{pH}$, and calcium salts. The concentration of cementation solution affects the size and distribution of calcium carbonate. In general, the concentration of the cementation solution is positively correlated with the curing effect. The content of calcium carbonate increases with the increase in the concentration of cementation solution. The deposition rate and crystal morphology of calcium carbonate were affected by the concentration of the bacterial solution. Therefore, it is necessary to determine the best concentration of bacteria to obtain the best curing effect. The culture temperature of the strain will affect the urease activity of the strain. The optimum culture temperature of different urease-producing bacteria was different, and the urease activity of most urease-producing bacteria reached the highest value when the culture temperature was $20-37^{\circ} \mathrm{C}$. The reaction temperature of MICP will affect the size of calcium carbonate. Many economic alternatives to calcium salts have been found, such as eggshells and seawater, etc. Calcium salts affect the precipitated $\mathrm{CaCO}_{3}$ content and calcite crystal type. The $\mathrm{pH}$ of the bacterial solution affects urease activity, thus affecting the precipitation of calcite and removing heavy metals. The $\mathrm{pH}$ of the cementation solution also affects the amount of precipitate. Most urease-producing bacteria have the highest urease activity at $\mathrm{pH} 8$. 
Based on the analysis of existing experiments on microbial sand consolidation, some problems and suggested topics for future research are summarized as follows:

(1) At present, micro-organism solidification faces some problems. For example, when microbe grouting enters sand and other media, $\mathrm{CaCO}_{3}$ deposit is not uniformly distributed, and induced $\mathrm{CaCO}_{3}$ deposit is deposited near the injection port. This may be due to an imbalance between the rate of hydrolysis of urea and the rate of transport of the cementation solution to the sand or the rapid precipitation rate of calcium carbonate generated at the injection port $[159,160]$. It needs to add the cementation solution several times in batches, and the cost is relatively high. In addition, the sand body after grouting needs to be heated and dried, and the operation is complicated. Wang et al. [161] added anion admixture based on the concept of ionic lattice energy. The introduction of anion admixtures can combine $\mathrm{Ca}^{2+}$ in the cementation solution to form ionic crystals, which can effectively reduce the number of grout times and avoid heating and drying this step after grout. However, the strength of sand consolidation is lower than that of other studies, so more efficient admixtures should be explored next.

(2) Urease-producing bacteria will produce the by-product of $\mathrm{NH}_{4}{ }^{+}$in the process of catalyzing urea hydrolysis. A high concentration of $\mathrm{NH}_{4}{ }^{+}$will harm the environment. At present, the research on ammonia removal mainly includes using natural zeolite to remove ammonium ions, the use of struvite to reduce ammonium by two steps, and reducing the $\mathrm{pH}$ in the reaction process to reduce ammonium ions [57-59]. More research on ammonium ion removal methods is needed in the future.

(3) There are also problems in solidifying sandy soil using the urease bacteria contained in the soil. It is troublesome to screen urease-producing bacteria in sandy soil, because of the need to carry out primary screening, re-screening, strain identification, and the urease activity of the selected strain may not be sufficient. However, the introduction of external bacteria could compete with bacteria inside the sand. In future, if measures can be taken to allow internal urea-producing bacteria and exogenous bacteria at the same time to solidify sand, this may be a promising research direction for the optimization of microbial sand consolidation.

(4) Although there are successful cases of microbial sand consolidation technology in field practice, there have been few large-scale experiments. Up until now, very few experiments on microbial sand consolidation technology have been conducted in deserts. Meng et al. [26] conducted field experiments with MICP in the Ulan Buh Desert and found that MICP can improve the resistance of sand to wind erosion. The high temperature of the desert made it easy for the solution to evaporate and posed a significant challenge to the survival of the species. Therefore, the treatment of sand by MICP is conducted after sunset. The effect of field sand consolidation experiments can be measured by the calcium carbonate content, the bearing capacity, and erosion depth of sand under wind conditions. When determining the optimal curing experimental conditions in the field, field environment and operation feasibility should be considered. The influences of temperature, $\mathrm{pH}$, bacterial liquid concentration, cementation solution concentration, and calcium source on MICP should be studied. MICP-treated sand has poor durability in harsh environments, such as wet-dry cycles, freeze-thaw cycles, and acid rain conditions [8]. There are few studies on the durability of MICP-treated sand under acid rain conditions, which can be studied more in the future. In addition, future research can overcome the adverse conditions of high temperatures by mutating genetic strains, thus achieving large-scale sand consolidation in deserts.

(5) Sand fixation methods include sand fixation with the sand barrier, chemical sand consolidation, and microbial sand consolidation. Each method has its advantages and disadvantages. Currently, most researchers use one curing method to solidify sandy soil, but no researchers to date have combined multiple curing methods to 
solidify sandy soil. This can be regarded as a future research direction in the field of solidifying sandy soil.

(6) Some experimental results have shown that the combined actions of non-urease bacteria and urease-producing bacteria enhance the microbial solidification of sandy soil. However, there have been few studies of the simultaneous use of non-urease bacteria and urease-producing bacteria to date. Gat et al. [162] found that the precipitation rate of calcium carbonate generated by non-urease bacteria B. subtilis and S. pasteurii was faster than that generated by S. pasteurii alone. They speculated that non-urease bacteria provided additional nucleation sites for MICP, which promoted the precipitation of calcium carbonate and accelerated the MICP process. This should be considered as a factor in the subsequent optimization of solidification experiments.

(7) The accuracy of the prediction results of the model will be affected by some factors. Kim et al. [163] found that the results predicted by the numerical model deviated from the actual value because the predicted results of the model were affected by factors such as the assumed shape of calcium carbonate particles and local pore blockage. Therefore, it was difficult to directly and accurately predict the pore-scale characteristics of MICP solidified sand through the model. Existing numerical models should be continuously optimized, and new numerical models should be proposed.

(8) Biological consolidation techniques mainly include the MICP method and another promising method, enzyme-induced carbonate precipitation (EICP) [164,165]. MICP produces urease using urease-producing bacteria in the culture environment, but the cultural environment of urease-producing bacteria is complicated, and urease activity is difficult to control [80]. EICP is derived from the direct use of free urease, and the enzymes can be derived from microbes, fungi, and agricultural sources. Microbially induced carbonate precipitation cannot treat sandy soils with pores smaller than $0.5 \mu \mathrm{m}$ because bacteria are 0.5 to $3 \mu \mathrm{m}$ in size. EICP can treat finer clays because the enzyme particle size is about $12 \mathrm{~nm}$ [80]. Compared with MICP, EICP has the advantage of not involving biosafety issues, while the calcium carbonate production efficiency of EICP is lower than that of MICP [166].

Author Contributions: L.C.: drafted the manuscript after conducting a literature search; Y.S.: initial idea, acquisition of funding, paper review \& revision; X.S.: acquisition of funding, supervision, paper review \& revision; H.F.: review \& revision of manuscript; J.H.: paper review \& revision; C.L.: paper review \& revision; H.J.: paper review \& revision; J.Z.: paper review \& revision. All authors have read and agreed to the published version of the manuscript.

Funding: The authors gratefully acknowledge Nanjing Forestry University Key Laboratory of For est Genetics and Biotechnology. The work was supported by the Natural Science Foundation of Jiangsu Province For Youth (BK20150874), and National Natural Science Foundation For Youth (31600463). The authors thank the Priority Academic Program Development of Jiangsu Higher Education Institution (PAPD) for supporting the work. This research is supported by the China Scholarship Council-Monash University Faculty of Engineering International Postgraduate Research Scholarship (CSC-Monash FEIPRS) joint project [Grant number: 201708320284].

Informed Consent Statement: Not applicable.

Data Availability Statement: Not applicable.

Conflicts of Interest: The authors declare no conflict of interest.

\section{References}

1. Portugal, C.R.M.E.; Fonyo, C.; Machado, C.C.; Meganck, R.; Jarvis, T. Microbiologically Induced Calcite Precipitation biocementation, green alternative for roads-is this the breakthrough? A critical review. J. Clean. Prod. 2020, 262, 121372. [CrossRef]

2. Wang, X.; Chen, F.; Hasi, E.; Li, J. Desertification in China: An assessment. Earth-Sci. Rev. 2008, 88, 188-206. [CrossRef]

3. Kimura, R.; Moriyama, M. Determination by MODIS satellite-based methods of recent global trends in land surface aridity and degradation. J. Agric. Meteorol. 2019, 75, 153-159. [CrossRef]

4. Huang, J.; Zhang, G.; Zhang, Y.; Guan, X.; Wei, Y.; Guo, R. Global desertification vulnerability to climate change and human activities. Land Degrad. Dev. 2020, 31, 1380-1391. [CrossRef] 
5. Mariina; Fahriani, F.; Apriyanti, Y. Utilization of palm kernel shell ash as stabilization materials for clay to settlement consolidation. In IOP Conference Series. Earth and Environmental Science; IOP Publishing Ltd.: Bangka, Indonesia, 2020 ; p. 599.

6. Yang, J.; Cheng, Y.; Chen, W. Experimental Study on Diffusion Law of Post-Grouting Slurry in Sandy Soil. Adv. Civ. Eng. 2019, 2019, 3493942. [CrossRef]

7. Ma, G.; Ran, F.; Feng, E.; Dong, Z.; Lei, Z. Effectiveness of an Eco-friendly Polymer Composite Sand-Fixing Agent on Sand Fixation. Water Air Soil Pollut. 2015, 226, 221. [CrossRef]

8. Liu, S.; Wen, K.; Armwood, C.; Bu, C.; Li, C.; Amini, F.; Li, L. Enhancement of MICP-Treated Sandy Soils against Environmental Deterioration. J. Mater. Civ. Eng. 2019, 31, 04019294. [CrossRef]

9. Qu, J.; Zu, R.; Zhang, K.; Fang, H. Field observations on the protective effect of semi-buried checkerboard sand barriers Geomorphology 2007, 88, 193-200. [CrossRef]

10. Pan, X.; Chu, J.; Yang, Y.; Cheng, L. A new biogrouting method for fine to coarse sand. Acta Geotech. 2019, 15, 1-16. [CrossRef]

11. Peng, S.; Di, H.; Fan, L.; Fan, W.; Qin, L. Factors Affecting Permeability Reduction of MICP for Fractured Rock. Front. Earth Sci. 2020, 8. [CrossRef]

12. Li, Y.; Sun, X.; Zhao, X.; Zhao, L.; Xu, S.; Gu, S.; Zhang, F.; Yu, G. Seasonal variations and mechanism for environmental con-trol of NEE of CO2 concerning the Potentilla fruticosa in alpine shrub meadow of Qinghai-Tibet Plateau. Sci. China Ser. D Earth Sci. 2006, 49, 174-185. [CrossRef]

13. Sharaky, A.M.; Mohamed, N.; Elmashad, M.E.; Shredah, N.M. Application of microbial biocementation to improve the physicomechanical properties of sandy soil. Constr. Build. Mater. 2018, 190, 861-869. [CrossRef]

14. Wang, Y.; Li, C.; Wang, C.; Gao, Y. Improving the Erosion Resistance Performance of Pisha Sandstone Weathered Soil Using MICP Technology. Crystals 2021, 11, 1112. [CrossRef]

15. Dejong, J.T.; Soga, K.; Kavazanjian, E.; Burns, S.; Van Paassen, L.A.; Al Qabany, A.; Aydilek, A.; Bang, S.S.; Burbank, M.; Caslake, L.F.; et al. Biogeochemical processes and geotechnical applications: Progress, opportunities and challenges. Géotechnique 2013, 63, 287-301. [CrossRef]

16. Mitchell, J.K.; Santamarina, J.C. Biological Considerations in Geotechnical Engineering. J. Geotech. Geoenviron. Eng. 2005, 131, 1222-1233. [CrossRef]

17. Mujah, D.; Shahin, M.A.; Cheng, L. State-of-the-Art Review of Biocementation by Microbially Induced Calcite Precipitation (MICP) for Soil Stabilization. Geomicrobiol. J. 2016, 34, 524-537. [CrossRef]

18. Han, Z.; Cheng, X.; Ma, Q. An experimental study on dynamic response for MICP strengthening liquefiable sands. Earthq. Eng. Eng. Vib. 2016, 15, 673-679. [CrossRef]

19. Eryürük, K.; Yang, S.; Suzuki, D.; Sakaguchi, I.; Akatsuka, T.; Tsuchiya, T.; Katayama, A. Reducing hydraulic conductivity of porous media using $\mathrm{CaCO}_{3}$ precipitation induced by Sporosarcina pasteurii. J. Biosci. Bioeng. 2015, 119, 331-336. [CrossRef]

20. Sasaki, T.; Kuwano, R. Undrained cyclic triaxial testing on sand with non-plastic fines content cemented with microbially induced $\mathrm{CaCO}_{3}$. Soils Found. 2016, 56, 485-495. [CrossRef]

21. Liu, B.; Zhu, C.; Tang, C.-S.; Xie, Y.-H.; Yin, L.-Y.; Cheng, Q.; Shi, B. Bio-remediation of desiccation cracking in clayey soils through microbially induced calcite precipitation (MICP). Eng. Geol. 2019, 264, 105389. [CrossRef]

22. Sun, X.; Miao, L.; Chen, R. Effects of different clay's percentages on improvement of Sand-Clay mixtures with microbially in-duced calcite precipitation. Geomicrobiol. J. 2019, 36, 810-818. [CrossRef]

23. Nassar, M.K.; Gurung, D.; Bastani, M.; Ginn, T.R.; Shafei, B.; Gomez, M.G.; Graddy, C.M.R.; Nelson, D.C.; Dejong, J.T. Large-scale experiments in microbially induced calcite precipitation (MICP): Reactive transport model development and predic-tion. Water Resour. Res. 2018, 54, 480-500. [CrossRef]

24. Lin, H.; Suleiman, M.T.; Jabbour, H.M.; Brown, D.G. Bio-grouting to enhance axial pull-out response of pervious concrete ground improvement piles. Can. Geotech. J. 2018, 55, 119-130. [CrossRef]

25. Liu, S.; Du, K.; Huang, W.; Wen, K.; Amini, F.; Li, L. Improvement of erosion-resistance of bio-bricks through fiber and mul-tiple MICP treatments. Constr. Build. Mater. 2021, 271, 121573. [CrossRef]

26. Meng, H.; Gao, Y.; He, J.; Qi, Y.; Hang, L. Microbially induced carbonate precipitation for wind erosion control of desert soil: Field-scale tests. Geoderma 2020, 383, 114723. [CrossRef]

27. Cunningham, A.B.; Class, H.; Ebigbo, A.; Gerlach, R.; Phillips, A.; Hommel, J. Field-scale modeling of microbially induced calcite precipitation. Comput. Geosci. 2018, 23, 399-414. [CrossRef]

28. Kadhim, F.J.; Zheng, J. Review of the factors that influence on the microbial induced calcite precipitation. J. Civ. Environ. Res. 2016, 8, 69-76.

29. Fang, C.; Achal, V. Biostimulation of calcite precipitation process by bacterial community in improving cement stabilized rammed earth as sustainable material. Appl. Microbiol. Biotechnol. 2019, 103, 7719-7727. [CrossRef]

30. Montoya, B.; DeJong, J.T. Stress-Strain Behavior of Sands Cemented by Microbially Induced Calcite Precipitation. J. Geotech. Geoenviron. Eng. 2015, 141, 04015019. [CrossRef]

31. Wangjie, L.; Chunxiang, Q.; Ruixing, W. Study on soil solidification based on microbiological precipitation of CaCO3. Sci. China Technol. Sci. 2010, 53, 2372-2377.

32. Sun, X.; Miao, L.; Chen, R.; Wang, H.; Xia, J. Surface rainfall erosion resistance and freeze-thaw durability of bio-cemented and polymer-modified loess slopes. J. Environ. Manag. 2021, 301, 113883. [CrossRef] 
33. Gebru, K.A.; Kidanemariam, T.G.; Gebretinsae, H.K. Bio-cement production using microbially induced calcite precipitation (MICP) method: A review. Chem. Eng. Sci. 2021, 238, 116610. [CrossRef]

34. Li, G. The countermeasures people should take facing desertification problem. J. Environ. Manag. Coll. China $2004,14,65-67$.

35. Sarlak, M.; Ferretti, L.V.; Biasi, R. The productive landscape in the desert margin for the sustainable development of rural settlements: An innovative greenbelt for maranjab desert in iran. Sustainability 2021, 13, 2077. [CrossRef]

36. DeJong, J.T.; Fritzges, M.B.; Nüsslein, K. Microbially Induced Cementation to Control Sand Response to Undrained Shear. J. Geotech. Geoenviron. Eng. 2006, 132, 1381-1392. [CrossRef]

37. Lin, H.; Suleiman, M.T.; Brown, D.G.; Kavazanjian, E., Jr. Mechanical behavior of sands treated by microbially induced car-bonate precipitation. J. Geotech. Geoenviron. Eng. 2016, 142, 4015066. [CrossRef]

38. Van Paassen, L.A.; Ghose, R.; Van der Linden, T.J.M.; Van der Star, W.R.L.; Van Loosdrecht, M.C.M. Quantifying biomediated ground improvement by ureolysis: Large-Scale biogrout experiment. J. Geotech. Geoenviron. Eng. 2010, 136, 1721-1728. [CrossRef]

39. Venuleo, S.; Laloui, L.; Terzis, D.; Hueckel, T.; Hassan, M. Microbially induced calcite precipitation effect on soil thermal conductivity. Géotechnique Lett. 2016, 6, 39-44. [CrossRef]

40. Hsu, C.-M.; Huang, Y.-H.; Nimje, V.R.; Lee, W.-C.; Chen, H.-J.; Kuo, Y.-H.; Huang, C.-H.; Chen, C.-C. Comparative Study on the Sand Bioconsolidation through Calcium Carbonate Precipitation by Sporosarcina pasteurii and Bacillus subtilis. Crystals 2018, 8, 189. [CrossRef]

41. Ivanov, V.; Chu, J. Applications of microorganisms to geotechnical engineering for bioclogging and biocementation of soil in situ. Rev. Environ. Sci. Bio/Technol. 2008, 7, 139-153. [CrossRef]

42. Achal, V.; Mukherjee, A.; Basu, P.C.; Reddy, M.S. Strain improvement of Sporosarcina pasteurii for enhanced urease and calcite production. J. Ind. Microbiol. Biotechnol. 2009, 36, 981-988. [CrossRef]

43. Soon, N.W.; Lee, L.M.; Khun, T.C.; Ling, H.S. Improvements in engineering properties of soils through microbial-induced calcite precipitation. KSCE J. Civ. Eng. 2013, 17, 718-728. [CrossRef]

44. Amarakoon, G.; Kawasaki, S. Factors Affecting Sand Solidification Using MICP with Pararhodobacter sp. Mater. Trans. 2018, 59, 72-81. [CrossRef]

45. Kim, G.; Youn, H. Microbially Induced Calcite Precipitation Employing Environmental Isolates. Materials 2016, 9, 468. [CrossRef] [PubMed]

46. Sarda, D.; Choonia, H.S.; Sarode, D.D.; Lele, S.S. Biocalcification by Bacillus pasteurii urease: A novel application. J. Ind. Microbiol. Biotechnol. 2009, 36, 1111-1115. [CrossRef] [PubMed]

47. Sarıçiçek, Y.E.; Gurbanov, R.; Pekcan, O.; Gozen, A.G. Comparison of microbially induced calcium carbonate precipitation eligibility using sporosarcina pasteurii and bacillus licheniformis on two different sands. Geomicrobiol. J. 2018, 36, 42-52. [CrossRef]

48. Ma, L.; Pang, A.-P.; Luo, Y.; Lu, X.; Lin, F. Beneficial factors for biomineralization by ureolytic bacterium Sporosarcina pasteurii. Microb. Cell Factories 2020, 19, 12. [CrossRef]

49. Cheng, L.; Shahin, M.A.; Cord-Ruwisch, R. Bio-cementation of sandy soil using microbial-induced carbonate precipitation (MICP) for marine environments. Géotechnique 2014, 64, 1010-1013. [CrossRef]

50. Kumari, D.; Pan, X.; Lee, D.-J.; Achal, V. Immobilization of cadmium in soil by microbially induced carbonate precipitation with Exiguobacterium undae at low temperature. Int. Biodeterior. Biodegrad. 2014, 94, 98-102. [CrossRef]

51. Dikshit, R.; Jain, A.; Dey, A.; Kumar, A. Microbially induced calcite precipitation using Bacillus velezensis with guar gum. PLoS ONE 2020, 15, e0236745. [CrossRef]

52. Rajasekar, A.; Moy, C.K.S.; Wilkinson, S.; Sekar, R. Microbially induced calcite precipitation performance of multiple land-fill indigenous bacteria compared to a commercially available bacteria in porous media. PLoS ONE 2021, 16, e254676. [CrossRef]

53. Gowthaman, S.; Iki, T.; Nakashima, K.; Ebina, K.; Kawasaki, S. Feasibility study for slope soil stabilization by microbial induced carbonate precipitation (MICP) using indigenous bacteria isolated from cold subarctic region. SN Appl. Sci. 2019, 1, 1480. [CrossRef]

54. Gowthaman, S. Microbial induced slope surface stabilization using industrial-grade chemicals: A preliminary laboratory study. Int. J. Geomate 2019, 17. [CrossRef]

55. Torres-Aravena, Á.; Duarte-Nass, C.; Azócar, L.; Mella-Herrera, R.; Rivas, M.; Jeison, D. Can microbially induced calcite precipitation (MICP) through a ureolytic pathway be successfully applied for removing heavy metals from wastewaters? Crystals 2018, 8, 438. [CrossRef]

56. Lee, M.; Gomez, M.G.; San Pablo, A.C.M.; Kolbus, C.M.; Graddy, C.M.R.; Dejong, J.T.; Nelson, D.C. Investigating ammonium by-product removal for ureolytic bio-cementation using meter-scale experiments. Sci. Rep. 2019, 9, 18313. [CrossRef] [PubMed]

57. Keykha, H.A.; Mohamadzadeh, H.; Asadi, A.; Kawasaki, S. Ammonium-Free Carbonate-Producing bacteria as an ecofriendly soil biostabilizer. Geotech. Test. J. 2019, 42, 19-29. [CrossRef]

58. Gowthaman, S.; Mohsenzadeh, A.; Nakashima, K.; Kawasaki, S. Removal of ammonium by-products from the effluent of bio-cementation system through struvite precipitation. Mater. Today Proc. 2021, in press. [CrossRef]

59. Gowthaman, S.; Yamamoto, M.; Nakashima, K.; Ivanov, V.; Kawasaki, S. Calcium phosphate biocement using bone meal and acid urease: An eco-friendly approach for soil improvement. J. Clean. Prod. 2021, 128782. [CrossRef]

60. Liu, D.; Shao, A.; Li, H.; Jin, C.; Li, Y. A study on the enhancement of the mechanical properties of weak structural planes based on microbiologically induced calcium carbonate precipitation. Bull. Int. Assoc. Eng. Geol. 2020, 79, 4349-4362. [CrossRef] 
61. Tiwari, N.; Satyam, N.; Sharma, M. Micro-mechanical performance evaluation of expansive soil biotreated with indigenous bacteria using MICP method. Sci. Rep. 2021, 11, 0324. [CrossRef]

62. Gowthaman, S.; Nakashima, K.; Kawasaki, S. Freeze-thaw durability and shear responses of cemented slope soil treated by microbial induced carbonate precipitation. Soils Found. 2020, 60, 840-855. [CrossRef]

63. Sharma, M.; Satyam, N.; Reddy, K.R. Effect of freeze-thaw cycles on engineering properties of biocemented sand under dif-ferent treatment conditions. Eng. Geol. 2021, 284, 106022. [CrossRef]

64. Sharma, M.; Satyam, N. Strength and durability of biocemented sands: Wetting-drying cycles, ageing effects, and liquefaction resistance. Geoderma 2021, 402, 115359. [CrossRef]

65. Gowthaman, S.; Nakashima, K.; Kawasaki, S. Durability analysis of bio-cemented slope soil under the exposure of acid rain. J. Soils Sediments 2021, 21, 2831-2844. [CrossRef]

66. Tobler, D.J.; Cuthbert, M.O.; Greswell, R.B.; Riley, M.S.; Renshaw, J.C.; Handley-Sidhu, S.; Phoenix, V.R. Comparison of rates of ureolysis between Sporosarcina pasteurii and an indigenous groundwater community under conditions required to precip-itate large volumes of calcite. Geochim. Cosmochim. Acta 2011, 75, 3290-3301. [CrossRef]

67. Feng, C.; Cui, B.; Ge, H.; Huang, Y.; Zhang, W.; Zhu, J. Reinforcement of recycled aggregate by Microbial-Induced mineralization and deposition of calcium carbonate-Influencing factors, mechanism and effect of reinforcement. Crystals 2021, 11, 887. [CrossRef]

68. Li, L.; Liu, T.; Jiang, G.; Fang, C.; Sun, J.; Zheng, S.; Liu, H.; Leusheva, E.; Morenov, V.; Nikolaev, N. Field application of mi-crobial Self-Healing cement slurry in chunguang 17-14 well. Energies 2021, 14, 1544. [CrossRef]

69. Achal, V.; Mukherjee, A.; Reddy, M.S. Effect of calcifying bacteria on permeation properties of concrete structures. J. Ind. Microbiol. Biotechnol. 2010, 38, 1229-1234. [CrossRef]

70. Achal, V.; Mukherjee, A.; Basu, P.C.; Reddy, M.S. Lactose mother liquor as an alternative nutrient source for microbial con-crete production by Sporosarcina pasteurii. J. Ind. Microbiol. Biotechnol. 2009, 36, 433-438. [CrossRef]

71. Omoregie, A.I.; Ngu, L.H.; Ong, D.E.L.; Nissom, P.M. Low-cost cultivation of Sporosarcina pasteurii strain in food-grade yeast extract medium for microbially induced carbonate precipitation (MICP) application. Biocatal. Agric. Biotechnol. 2019, 17, 247-255. [CrossRef]

72. Cuzman, O.A.; Richter, K.; Wittig, L.; Tiano, P. Alternative nutrient sources for biotechnological use of Sporosarcina pasteurii. World J. Microbiol. Biotechnol. 2015, 31, 897-906. [CrossRef] [PubMed]

73. Chaparro, S.; Rojas, H.; Caicedo, G.; Romanelli, G.; Pineda, A.; Luque, R.; Martínez, J. Whey as an Alternative Nutrient Medium for Growth of Sporosarcina pasteurii and Its Effect on $\mathrm{CaCO}_{3}$ Polymorphism and Fly Ash Bioconsolidation. Materials 2021, 14, 2470. [CrossRef] [PubMed]

74. Amiri, A.; Bundur, Z.B. Use of corn-steep liquor as an alternative carbon source for biomineralization in cement-based materials and its impact on performance. Constr. Build. Mater. 2018, 165, 655-662. [CrossRef]

75. Yoosathaporn, S.; Tiangburanatham, P.; Bovonsombut, S.; Chaipanich, A.; Pathom-Aree, W. A cost effective cultivation medium for biocalcification of Bacillus pasteurii KCTC 3558 and its effect on cement cubes properties. Microbiol. Res. 2016, 186, 132-138. [CrossRef]

76. Gowthaman, S.; Mitsuyama, S.; Nakashima, K.; Komatsu, M.; Kawasaki, S. Biogeotechnical approach for slope soil stabiliza-tion using locally isolated bacteria and inexpensive low-grade chemicals: A feasibility study on Hokkaido expressway soil, Japan. Soils Found. 2019, 59, 484-499. [CrossRef]

77. Pan, X.; Wang, Z.; Gao, Y. Effects of compound sand barrier for habitat restoration on sediment grain-size distribution in ulan buh desert. Sci. Rep. 2020, 10, 2566. [CrossRef]

78. Ahenkorah, I.; Rahman, M.M.; Karim, M.R.; Beecham, S. Enzyme induced calcium carbonate precipitation and its engineer-ing application: A systematic review and meta-analysis. Constr. Build. Mater. 2021, 308, 125000. [CrossRef]

79. Huang, N.; Xia, X.; Tong, D. Numerical simulation of wind sand movement in straw checkerboard barriers. Eur. Phys. J. E 2013, 36, 99. [CrossRef]

80. Almajed, A.; Lateef, M.A.; Moghal, A.A.B.; Lemboye, K. State-of-the-Art review of the applicability and challenges of Microbial-Induced calcite precipitation (MICP) and Enzyme-Induced calcite precipitation (EICP) techniques for geotechnical and geoenvironmental applications. Crystals 2021, 11, 370. [CrossRef]

81. Imran, M.A.; Nakashima, K.; Kawasaki, S. Bio-Mediated soil improvement using plant derived enzyme in addition to mag-nesium ion. Crystals 2021, 11, 516. [CrossRef]

82. Gomez, M.G.; Graddy, C.M.R.; DeJong, J.T.; Nelson, D.C. Biogeochemical Changes During Bio-cementation Mediated by Stimulated and Augmented Ureolytic Microorganisms. Sci. Rep. 2019, 9, 11517. [CrossRef]

83. Bernardi, D.; DeJong, J.; Montoya, B.; Martinez, B. Bio-bricks: Biologically cemented sandstone bricks. Constr. Build. Mater. 2014, 55, 462-469. [CrossRef]

84. Nafisi, A.; Safavizadeh, S.; Montoya, B.M. Influence of Microbe and Enzyme-Induced Treatments on Cemented Sand Shear Response. J. Geotech. Geoenviron. Eng. 2019, 145, 06019008. [CrossRef]

85. Ahenkorah, I.; Rahman, M.M.; Karim, M.R.; Teasdale, P.R. A comparison of mechanical responses for microbial- and en-zymeinduced cemented sand. Géotechnique Lett. 2020, 10, 559-567. [CrossRef]

86. Cheng, L.; Shahin, M.A.; Chu, J. Soil bio-cementation using a new one-phase low-pH injection method. Acta Geotech. 2019, 14, 615-626. [CrossRef] 
87. Xu, H.; Zheng, H.; Wang, J.; Ding, X.; Chen, P. Laboratory method of microbial induced solidification/stabilization for mu-nicipal solid waste incineration fly ash. MethodsX 2019, 6, 1036-1043. [CrossRef] [PubMed]

88. Wang, Z.; Zhang, N.; Ding, J.; Lu, C.; Jin, Y. Experimental Study on Wind Erosion Resistance and Strength of Sands Treated with Microbial-Induced Calcium Carbonate Precipitation. Adv. Mater. Sci. Eng. 2018, 2018, 1-10. [CrossRef]

89. Jroundi, F.; Schiro, M.; Ruiz-Agudo, E.; Elert, K.; Martín-Sánchez, I.; González-Muñoz, M.T.; Rodriguez-Navarro, C. Protection and consolidation of stone heritage by self-inoculation with indigenous carbonatogenic bacterial communities. Nat. Commun. 2017, 8, 279. [CrossRef]

90. Burbank, M.B.; Weaver, T.J.; Green, T.L.; Williams, B.C.; Crawford, R.L. Precipitation of calcite by indigenous microorganisms to strengthen liquefiable soils. Geomicrobiol. J. 2011, 28, 301-312. [CrossRef]

91. Cheng, L.; Shahin, M.A.; Cord-Ruwisch, R. Surface Percolation for Soil Improvement by Biocementation Utilizing In Situ Enriched Indigenous Aerobic and Anaerobic Ureolytic Soil Microorganisms. Geomicrobiol. J. 2016, 34, 546-556. [CrossRef]

92. Burbank, M.B.; Weaver, T.J.; Williams, B.C.; Crawford, R.L. Urease Activity of Ureolytic Bacteria Isolated from Six Soils in which Calcite was Precipitated by Indigenous Bacteria. Geomicrobiol. J. 2012, 29, 389-395. [CrossRef]

93. Burbank, M.; Weaver, T.; Lewis, R.; Williams, T.; Williams, B.; Crawford, R. Geotechnical tests of sands following bioinduced calcite precipitation catalyzed by indigenous bacteria. J. Geotech. Geoenviron. Eng. 2013, 139, 928-936. [CrossRef]

94. Chahal, N.; Siddique, R. Permeation properties of concrete made with fly ash and silica fume: Influence of ureolytic bacteria. Constr. Build. Mater. 2013, 49, 161-174. [CrossRef]

95. Wang, Y.-J.; Han, X.-L.; Jiang, N.-J.; Wang, J.; Feng, J. The effect of enrichment media on the stimulation of native ureolytic bacteria in calcareous sand. Int. J. Environ. Sci. Technol. 2019, 17, 1795-1808. [CrossRef]

96. Khan, M.N.H.; Amarakoon, G.G.N.N.; Shimazaki, S.; Kawasaki, S. Coral sand solidification test based on microbially induced carbonate precipitation using ureolytic bacteria. Mater. Trans. 2015, 56, 1725-1732. [CrossRef]

97. Oualha, M.; Bibi, S.; Sulaiman, M.; Zouari, N. Microbially induced calcite precipitation in calcareous soils by endogenous Bacillus cereus, at high $\mathrm{pH}$ and harsh weather. J. Environ. Manag. 2019, 257, 109965. [CrossRef] [PubMed]

98. Song, W.; Yang, Y.; Qi, R.; Li, J.; Pan, X. Suppression of coal dust by microbially induced carbonate precipitation usingStaphylococcus succinus. Environ. Sci. Pollut. Res. 2019, 26, 35968-35977. [CrossRef]

99. Imran, M.A.; Nakashima, K.; Evelpidou, N.; Kawasaki, S. Factors affecting the urease activity of native ureolytic bacteria isolated from coastal areas. Geomech. Eng. 2019, 17, 421-427.

100. Chu, J.; Stabnikov, V.; Ivanov, V. Microbially Induced Calcium Carbonate Precipitation on Surface or in the Bulk of Soil. Geomicrobiol. J. 2012, 29, 544-549. [CrossRef]

101. Phillips, A.J.; Lauchnor, E.; Eldring, J.; Esposito, R.; Mitchell, A.C.; Gerlach, R.; Cunningham, A.B.; Spangler, L.H. Potential CO 2 Leakage Reduction through Biofilm-Induced Calcium Carbonate Precipitation. Environ. Sci. Technol. 2012, 47, 142-149. [CrossRef]

102. Cheng, L.; Cord-Ruwisch, R. Upscaling Effects of Soil Improvement by Microbially Induced Calcite Precipitation by Surface Percolation. Geomicrobiol. J. 2014, 31, 396-406. [CrossRef]

103. Cuthbert, M.O.; McMillan, L.A.; Handley-Sidhu, S.; Riley, M.S.; Tobler, D.J.; Phoenix, V.R. A Field and Modeling Study of Fractured Rock Permeability Reduction Using Microbially Induced Calcite Precipitation. Environ. Sci. Technol. 2013, 47, 13637-13643. [CrossRef]

104. van Paassen, L.A. Bio-Mediated Ground Improvement: From Laboratory Experiment to Pilot Applications. In Geo-Frontiers 2011: Advances in Geotechnical Engineering; ASCE: Reston, VA, USA, 2011. [CrossRef]

105. Harkes, M.P.; van Paassen, L.A.; Booster, J.L.; Whiffin, V.S.; van Loosdrecht, M.C.M. Fixation and distribution of bacterial activity in sand to induce carbonate precipitation for ground reinforcement. Ecol. Eng. 2010, 36, 112-117. [CrossRef]

106. Ohan, J.A.; Saneiyan, S.; Lee, J.; Bartlow, A.W.; Ntarlagiannis, D.; Burns, S.E.; Colwell, F.S. Microbial and geochemical dy-namics of an aquifer stimulated for microbial induced calcite precipitation (MICP). Front. Microbiol. 2020, 11, 1327. [CrossRef] [PubMed]

107. Feng, K.; Montoya, B.; Evans, T. Discrete element method simulations of bio-cemented sands. Comput. Geotech. 2017, 85, 139-150. [CrossRef]

108. Fauriel, S.; Laloui, L. A bio-chemo-hydro-mechanical model for microbially induced calcite precipitation in soils. Comput. Geotech 2012, 46, 104-120. [CrossRef]

109. Connolly, J.; Kaufman, M.; Rothman, A.; Gupta, R.; Redden, G.; Schuster, M.; Colwell, F.; Gerlach, R. Construction of two ureolytic model organisms for the study of microbially induced calcium carbonate precipitation. J. Microbiol. Methods 2013, 94, 290-299. [CrossRef]

110. Gai, X.; Sánchez, M. An elastoplastic mechanical constitutive model for microbially mediated cemented soils. Acta Geotech. 2018, 14, 709-726. [CrossRef]

111. Wang, X.; Nackenhorst, U. A coupled bio-chemo-hydraulic model to predict porosity and permeability reduction during microbially induced calcite precipitation. Adv. Water Resour. 2020, 140, 103563. [CrossRef]

112. Martinez, B.C.; Dejong, J.T.; Ginn, T.R. Bio-geochemical reactive transport modeling of microbial induced calcite precipitation to predict the treatment of sand in one-dimensional flow. Comput. Geotech. 2014, 58, 1-13. [CrossRef]

113. Colwell, F.S.; Smith, R.W.; Ferris, F.G.; Reysenbach, A.; Fujita, Y.; Tyler, T.L.; Taylor, J.L.; Banta, A.; Delwiche, M.E.; Mcling, T.L.; et al. Microbially mediated subsurface calcite precipitation for removal of hazardous divalent cations: Microbial activity, molecular biology, and modeling. Subsurf. Contam. Remediat. 2005, 904, 117-137. 
114. Yang, P.; Kavazanjian, E.; Neithalath, N. Particle-Scale Mechanisms in Undrained Triaxial Compression of Biocemented Sands: Insights from 3D DEM Simulations with Flexible Boundary. Int. J. Géoméch. 2019, 19, 04019009. [CrossRef]

115. Tobler, D.J.; Cuthbert, M.O.; Phoenix, V.R. Transport of Sporosarcina pasteurii in sandstone and its significance for subsurface engineering technologies. Appl. Geochem. 2014, 42, 38-44. [CrossRef]

116. Qin, C.; Hassanizadeh, S.M.; Ebigbo, A. Pore-scale network modeling of microbially induced calcium carbonate precipita-tion: Insight into scale dependence of biogeochemical reaction rates. Water Resour. Res. 2016, 52, 8794-8810. [CrossRef]

117. Wang, Z.; Zhang, N.; Ding, J.; Li, Q.; Xu, J. Thermal conductivity of sands treated with microbially induced calcite precipita-tion (MICP) and model prediction. Int. J. Heat Mass Tran. 2020, 147, 118899. [CrossRef]

118. DeJong, J.; Martinez, B.C.; Ginn, T.R.; Hunt, C.; Major, D.; Tanyu, B. Development of a Scaled Repeated Five-Spot Treatment Model for Examining Microbial Induced Calcite Precipitation Feasibility in Field Applications. Geotech. Test. J. 2014, 37. [CrossRef]

119. Minto, J.M.; Lunn, R.J.; El Mountassir, G. Development of a Reactive Transport Model for Field-Scale Simulation of Microbially Induced Carbonate Precipitation. Water Resour. Res. 2019, 55, 7229-7245. [CrossRef]

120. Ebigbo, A.; Phillips, A.; Gerlach, R.; Helmig, R.; Cunningham, A.B.; Class, H.; Spangler, L.H. Darcy-scale modeling of mi-crobially induced carbonate mineral precipitation in sand columns. Water Resour. Res. 2012, 48, 1-17. [CrossRef]

121. Al Qabany, A.; Soga, K.; Santamarina, C. Factors Affecting Efficiency of Microbially Induced Calcite Precipitation. J. Geotech. Geoenvironmental Eng. 2012, 138, 992-1001. [CrossRef]

122. Soon, N.W.; Lee, L.M.; Khun, T.C.; Ling, H.S. Factors Affecting Improvement in Engineering Properties of Residual Soil through Microbial-Induced Calcite Precipitation. J. Geotech. Geoenviron. Eng. 2014, 140, 04014006. [CrossRef]

123. Sotoudehfar, A.R.; Sadeghi, M.M.; Mokhtari, E.; Shafiei, F. Assessment of the Parameters Influencing Microbial Calcite Precipitation in Injection Experiments Using Taguchi Methodology. Geomicrobiol. J. 2015, 33, 163-172. [CrossRef]

124. Keykhahamed, A.; Asadi, A.; Huatbujang, B.K.; Kawasaki, S. Microbial induced calcite precipitation by Sporosarcina pasteurii and Sporosarcina aquimarina. Environ. Geotech. 2018, 6, 562-566.

125. Xu, J.; Tang, Y.; Wang, X. A correlation study on optimum conditions of microbial precipitation and prerequisites for self-healing concrete. Process. Biochem. 2020, 94, 266-272. [CrossRef]

126. Omoregie, A.I.; Palombo, E.A.; Ong, D.E.L.; Nissom, P.M. Biocementation of sand by Sporosarcina pasteurii strain and tech-nicalgrade cementation reagents through surface percolation treatment method. Constr. Build. Mater. 2019, 228, 116828. [CrossRef]

127. Seifan, M.; Samani, A.K.; Berenjian, A. Induced calcium carbonate precipitation using Bacillus species. Appl. Microbiol. Biotechnol. 2016, 100, 9895-9906. [CrossRef]

128. Liu, J.; Li, J.; Xie, X.; Xu, C.; Zheng, L. Experimental study on the strength of silt soil solidified by MICP. Low Temp. Archit. Technol. 2020, 42, 17-20.

129. Duo, L.; Kan-Liang, T.; Hui-Li, Z.; Yu-Yao, W.; Kang-Yi, N.; Shi-Can, Z. Experimental investigation of solidifying desert aeolian sand using microbially induced calcite precipitation. Constr. Build. Mater. 2018, 172, 251-262. [CrossRef]

130. Qabany, A.; Soga, K. Effect of chemical treatment used in MICP on engineering properties of cemented soils. Géotechnique 2013, 63, 331-339. [CrossRef]

131. Mujah, D.; Cheng, L.; Shahin, M. Microstructural and Geomechanical Study on Biocemented Sand for Optimization of MICP Process. J. Mater. Civ. Eng. 2019, 31, 04019025. [CrossRef]

132. Whitaker, J.M.; Vanapalli, S.; Fortin, D. Improving the strength of sandy soils via ureolytic CaCO3 solidification by Sporo-sarcina ureae. Biogeosciences 2018, 15, 4367-4380. [CrossRef]

133. Chen, F.; Deng, C.; Song, W.; Zhang, D.; Al-Misned, F.A.; Mortuza, M.G.; Gadd, G.M.; Pan, X. Biostabilization of Desert Sands Using Bacterially Induced Calcite Precipitation. Geomicrobiol. J. 2016, 33, 243-249. [CrossRef]

134. Jiang, N.-J.; Tang, C.-S.; Yin, L.-Y.; Xie, Y.-H.; Shi, B. Applicability of Microbial Calcification Method for Sandy-Slope Surface Erosion Control. J. Mater. Civ. Eng. 2019, 31, 04019250. [CrossRef]

135. Chahal, N.; Siddique, R.; Rajor, A. Influence of bacteria on the compressive strength, water absorption and rapid chloride permeability of concrete incorporating silica fume. Constr. Build. Mater. 2012, 37, 645-651. [CrossRef]

136. Wen, K.; Li, Y.; Amini, F.; Li, L. Impact of bacteria and urease concentration on precipitation kinetics and crystal morphology of calcium carbonate. Acta Geotech. 2020, 15, 17-27. [CrossRef]

137. Andalib, R.; Majid, M.Z.A.; Hussin, M.W.; Ponraj, M.; Keyvanfar, A.; Mirza, J.; Lee, H.-S. Optimum concentration of Bacillus megaterium for strengthening structural concrete. Constr. Build. Mater. 2016, 118, 180-193. [CrossRef]

138. Omoregie, A.; Khoshdelnezamiha, G.; Senian, N.; Ong, D.E.L.; Nissom, P.M. Experimental optimisation of various cultural conditions on urease activity for isolated Sporosarcina pasteurii strains and evaluation of their biocement potentials. Ecol. Eng. 2017, 109, 65-75. [CrossRef]

139. Fujita, M.; Nakashima, K.; Achal, V.; Kawasaki, S. Whole-cell evaluation of urease activity of Pararhodobacter sp. isolated from peripheral beachrock. Biochem. Eng. J. 2017, 124, 1-5. [CrossRef]

140. Kim, G.; Kim, J.; Youn, H. Effect of Temperature, pH, and Reaction Duration on Microbially Induced Calcite Precipitation. Appl. Sci. 2018, 8, 1277. [CrossRef]

141. Imran, A.; Shinmura, M.; Nakashima, K.; Kawasaki, S. Effects of Various Factors on Carbonate Particle Growth Using Ureolytic Bacteria. Mater. Trans. 2018, 59, 1520-1527. [CrossRef]

142. Deng, W.; Wang, Y. Investigating the Factors Affecting the Properties of Coral Sand Treated with Microbially Induced Calcite Precipitation. Adv. Civ. Eng. 2018, 2018, 1-6. [CrossRef] 
143. Cheng, L.; Shahin, M.A.; Mujah, D. Influence of Key Environmental Conditions on Microbially Induced Cementation for Soil Stabilization. J. Geotech. Geoenviron. Eng. 2017, 143, 04016083. [CrossRef]

144. Yang, Y.; Chu, J.; Cao, B.; Liu, H.; Cheng, L. Biocementation of soil using non-sterile enriched urease-producing bacteria from activated sludge. J. Clean. Prod. 2020, 262, 121315. [CrossRef]

145. Wu, M.; Hu, X.; Zhang, Q.; Xue, D.; Zhao, Y. Growth environment optimization for inducing bacterial mineralization and its application in concrete healing. Constr. Build. Mater. 2019, 209, 631-643. [CrossRef]

146. Alonso, M.J.C.; Ortiz, C.E.L.; Perez, S.O.G.; Narayanasamy, R.; Miguel, G.D.J.F.S.; Hernández, H.H.; Balagurusamy, N. Improved strength and durability of concrete through metabolic activity of ureolytic bacteria. Environ. Sci. Pollut. Res. 2017, 25, 21451-21458. [CrossRef]

147. Zhao, Y.; Yao, J.; Yuan, Z.; Wang, T.; Zhang, Y.; Wang, F. Bioremediation of Cd by strain GZ-22 isolated from mine soil based on biosorption and microbially induced carbonate precipitation. Environ. Sci. Pollut. Res. 2016, 24, 372-380. [CrossRef] [PubMed]

148. Wu, C.; Chu, J.; Cheng, L.; Wu, S. Biogrouting of aggregates using premixed injection method with or without $\mathrm{pH}$ adjustment. J. Mater. Civil Eng. 2019, 31, 06019008. [CrossRef]

149. Gorospe, C.M.; Han, S.; Kim, S.; Park, J.; Kang, C.; Jeong, J.; So, J. Effects of different calcium salts on calcium carbonate crystal formation by Sporosarcina pasteurii KCTC 3558. Biotechnol. Bioprocess Eng. 2013, 18, 903-908. [CrossRef]

150. Dong, Y.; Guo, Z.; Guo, N.; Liu, T. One-Step Removal of Calcium, Magnesium, and Nickel in Desalination by Alcaligenes aquatilis via Biomineralization. Crystals 2019, 9, 633. [CrossRef]

151. Røyne, A.; Phua, Y.J.; Balzer Le, S.; Eikjeland, I.G.; Josefsen, K.D.; Markussen, S.; Myhr, A.; Throne-Holst, H.; Sikorski, P.; Wentzel, A. Towards a low CO2 emission building material employing bacterial metabolism (1/2): The bacterial system and prototype production. PLoS ONE 2019, 14, e212990. [CrossRef] [PubMed]

152. Choi, S.G.; Chu, J.; Brown, R.C.; Wang, K.; Wen, Z. Sustainable biocement production via microbially induced calcium car-bonate precipitation: Use of limestone and acetic acid derived from pyrolysis of lignocellulosic biomass. ACS Sustain. Chem. Eng. 2017, 5, 5183-5190. [CrossRef]

153. Choi, S.; Wu, S.; Chu, J. Biocementation for sand using an eggshell as calcium source. J. Geotech. Geoenviron. Eng. 2016, 142, 06016010. [CrossRef]

154. Liang, S.; Chen, J.; Niu, J.; Gong, X.; Feng, D. Using recycled calcium sources to solidify sandy soil through microbial in-duced carbonate precipitation. Mar. Georesour. Geotec. 2020, 38, 393-399. [CrossRef]

155. Liu, L.; Liu, H.; Xiao, Y.; Chu, J.; Xiao, P.; Wang, Y. Biocementation of calcareous sand using soluble calcium derived from calcareous sand. Bull. Int. Assoc. Eng. Geol. 2017, 77, 1781-1791. [CrossRef]

156. Pan, L.; Li, Q.; Zhou, Y.; Song, N.; Yu, L.; Wang, X.; Xiong, K.; Yap, L.; Huo, J. Effects of different calcium sources on the min-eralization and sand curing of $\mathrm{CaCO} 3$ by carbonic anhydrase-producing bacteria. RSC Adv. 2019, 9, 40827-40834. [CrossRef]

157. Zhang, Y.; Guo, H.; Cheng, X. Role of calcium sources in the strength and microstructure of microbial mortar. Constr. Build. Mater. 2015, 77, 160-167. [CrossRef]

158. Abo-El-Enein, S.; Ali, A.; Talkhan, F.N.; Abdel-Gawwad, H. Utilization of microbial induced calcite precipitation for sand consolidation and mortar crack remediation. HBRC J. 2012, 8, 185-192. [CrossRef]

159. Whiffin, V.S.; van Paassen, L.; Harkes, M.P. Microbial Carbonate Precipitation as a Soil Improvement Technique. Geomicrobiol. J. 2007, 24, 417-423. [CrossRef]

160. Wu, C.; Chu, J.; Wu, S.; Cheng, L.; van Paassen, L. Microbially induced calcite precipitation along a circular flow channel under a constant flow condition. Acta Geotech. 2018, 14, 673-683. [CrossRef]

161. Wang, L.; Li, K.; Fu, P.; Li, N.; Zhao, W. Preliminary laboratory study on microbial slurry admixture for sand reinforcement. J. China Inst. Water Resour. Hydropower Res. 2020, 18, 130-135.

162. Gat, D.; Tsesarsky, M.; Shamir, D.; Ronen, Z. Accelerated microbial-induced $\mathrm{CaCO}_{3}$ precipitation in a defined coculture of ureolytic and non-ureolytic bacteria. Biogeosciences 2014, 11, 2561-2569. [CrossRef]

163. Kim, D.; Mahabadi, N.; Jang, J.; van Paassen, L.A. Assessing the Kinetics and Pore-Scale Characteristics of Biological Calcium Carbonate Precipitation in Porous Media using a Microfluidic Chip Experiment. Water Resour. Res. 2020, 56. [CrossRef]

164. Arab, M.G.; Omar, M.; Almajed, A.; Elbaz, Y.; Ahmed, A.H. Hybrid technique to produce bio-bricks using enzyme-induced carbonate precipitation (EICP) and sodium alginate biopolymer. Constr. Build. Mater. 2021, 284, 122846. [CrossRef]

165. Almajed, A.; Abbas, H.; Arab, M.; Alsabhan, A.; Hamid, W.; Al-Salloum, Y. Enzyme-Induced Carbonate Precipitation (EICP)Based methods for ecofriendly stabilization of different types of natural sands. J. Clean. Prod. 2020, 274, 122627. [CrossRef]

166. Cui, M.; Lai, H.; Hoang, T.; Chu, J. One-phase-low-pH enzyme induced carbonate precipitation (EICP) method for soil improvement. Acta Geotech. 2021, 16, 481-489. [CrossRef] 